\title{
Taxonomy of Probolodus Eigenmann, 1911 (Characiformes: Characidae) with description of two new species, and comments about the phylogenetic relationships and biogeography of the genus
}

\author{
Osmar Santos and Ricardo M. C. Castro
}

Probolodus is a genus of tetras distributed along the coastal basins of southeastern Brazil, from Espírito Santo on the north, to São Paulo states. It was proposed by Eigenmann in 1911, to include the single species P. heterostomus. However, examining of material recently collected we identified two new species: P. oyakawai, new species, from the rio Ribeira de Iguape basin, and $P$. sazimai, new species, from the rio Itapemirim (Espírito Santo), and drainages of the rio Doce basin (Espírito Santo and Minas Gerais states). Therefore, the distribution of P. heterostomus was restricted to the rio Paraíba do Sul basin, southeastern Brazil. The genus Probolodus was redefined based on osteological characters, in particular details of oral dentition. Probolodus heterostomus differs from its congeners by a combination of meristic and osteological characters. An identification key for the species of the genus is presented. The possible evolutionary relationships of Probolodus with other characids, especially some lepidophagous taxa are discussed. Regarding the biogeography of the group, some geological events are hypothesized as responsible for the cladogenetic events among species of the genus.

Probolodus é um gênero de lambari distribuído ao longo das bacias costeiras do sudeste brasileiro, do Espírito Santo até São Paulo. Foi proposto originalmente por Eigenmann em 1911, para abrigar a única espécie $P$. heterostomus. Entretanto, através do exame de material coletado recentemente, identificamos duas novas espécies do gênero: P. oyakawai, espécie nova, da bacia do rio Ribeira de Iguape, e P. sazimai, espécie nova, das drenagens das bacias dos rios Itapemirim (Espírito Santo) e Doce (Espírito Santo e Minas Gerais). Portanto, a distribuição de P. heterostomus foi restringida à bacia do rio Paraíba do Sul, sudeste do Brasil. O gênero Probolodus foi redefinido a partir de caracteres osteológicos, em especial detalhes da dentição. Probolodus heterostomus difere de suas duas congêneres por uma combinação de caracteres merísticos e osteológicos. Uma chave de identificação do gênero é apresentada. As possíveis relações evolutivas de Probolodus com outros caracídeos, em especial alguns táxons lepidófagos examinados neste estudo, são discutidas. Com relação à biogeografia do gênero, alguns eventos geológicos são postulados como possivelmente responsáveis pela sua cladogênese.

Key words: Atlantic coastal basins, Lambari, Lepidophagous, Neotropics, Probolodus heterostomus.

\section{Introduction}

Probolodus was described by Eigenmann (1911) based on six specimens collected by John D. Haseman along the coastal basins of southeastern Brazil, four of them collected in the rio Paraíba do Sul basin, in Rio de Janeiro State, and two collected in the rio Ribeira de Iguape basin, in São Paulo State.

The monotypic genus Probolodus composed by a single species, $P$. heterostomus, was placed by Eigenmann (1911) in the subfamily Aphyocharacinae and distinguished from other genera of the subfamily by the following peculiarities of its dentition: the presence of three tricuspid teeth in the premaxillary directed slightly outward; maxilla with three to five teeth, the first two or three directed slightly outward; dentary with four large strong conical teeth, with minute cusps on each side, directed slightly outward.

However, based mainly in characteristics of the dentition, such as well-developed teeth arranged in a single series, comparatively few in number, structure and arrangement of teeth in the premaxillary, maxillary and dentary, Eigenmann

Laboratório de Ictiologia de Ribeirão Preto, Departamento de Biologia, Programa de Pós-Graduação em Biologia Comparada, Universidade de São Paulo. Av. dos Bandeirantes 3900, 14040-901 Ribeirão Preto, SP, Brazil. osmysantos@yahoo.com.br, rmcastro@ffclrp.usp.br 
(1915) created the subfamily Cheirodontinae. In this subfamily the author placed the genus Probolodus and 19 other characid genera, such as Grundulus, Spintherobolus, Aphyocharax, Paragoniates, Oligobrycon, Mixobrycon, Odontostilbe. Latter on Géry (1977), based on Eigenmann (1915), considered the subfamily Cheirodontinae a polyphyletic group of fishes with tricuspidate or conical teeth, and created, among others, the tribe Probolodini, composed solely by P. heterostomus, characterized by having tricuspidate teeth directed outward, which allow them to eat scales of other fishes.

More recently, a new definition was proposed by L. Malabarba (1998) for this subfamily based on derived characters related to dental morphology, muscle coverage over the anterior region of the gas bladder and color pattern of the humeral region. With this definition, Probolodus and other genera, such as Aphyoditae, Leptagoniates, Leptobrycon, Microschemobrycon, Mixobrycon, and Prionobrama were excluded from the Cheirodontinae, and were considered incertae sedis in Characidae (Lima et al., 2003). However, in the phylogenetic hypothesis of Mirande (2010), the subfamilies Stethaprioninae and Tetragonopterinae (sensu Reis, 2003) were validated, and the characids forming his "Hemigrammus clade" (Mirande, 2009 - node 275) were grouped in a monophyletic Tetragonopterinae (Mirande, 2010 - node 224). Still according to Mirande (2010) the monophyly of Tetragonopterinae is supported by a single homoplastic synapomorphy, and $P$. heterostomus is the sister-group of all taxa comprising the node 224, therefore part of the Tetragonopterinae sensu Mirande (2010).

Recently, based mostly on molecular characters, Oliveira et al. (2011) considered the genus Probolodus part of their clade 37, the Family Characidae, which is characterized morphologically by the lack of a supraorbital bone in its members, together with the emergence of the hyoid artery from the anterior ceratohyal proximate to the articulation of that bone with the posterior ceratohyal; furthermore, Oliveira et al. (2011), considered Probolodus part of an "interesting and well supported group" formed by Stygichthys typhlops and Coptobrycon bilineatus, as sister group of Probolodus heterostomus, Deuterodon iguape and Myxiops aphos, all inhabitants of very ancient land formations in the northeastern and southeastern regions of Brazil, which are also the areas of residence of primitive lineages in other groups of fishes such as the Trichomycteridae and Loricariidae.

The species of Probolodus reach about $110 \mathrm{~mm}$ of standard length (SL) and the genus is distributed throughout coastal basins of southeastern Brazil, from Espírito Santo to São Paulo states, quite commonly caught in black waters and sometimes in clear waters streams (Sazima, 1977; Reis et al., 2003; Menezes et al., 2007).

Until this study, Probolodus was regarded as a monotypic genus with the only valid species, P. heterostomus. However, based on the examination of ichthyological material deposited in various Brazilian collections, two new species were identified: P. oyakawai, from the rio Ribeira de Iguape basin, State of São Paulo, and P. sazimai, from the drainages of the rio Doce basin and rio Itapemirim basin, Minas Gerais and Espírito Santo states, both in southeastern Brazil. Thus, the present study aims to redescribe the genus Probolodus and its type species $P$. heterostomus, and also to describe the two new species. In addition, an identification key to the species of the genus is presented, and the phylogenetic relationships and biogeography of Probolodus are discussed.

\section{Material and Methods}

Measurements and counts were made on left side on the specimen whenever possible. All measurements were made point-to-point. Morphometric values were taken with digital calipers and expressed to the nearest $0.1 \mathrm{~mm}$. Measurements of subunits of the body and of head length are given as proportions of standard length (SL) except for subunits of the head that are presented as proportions of head length (HL). Lateral-line scale counts include all pored scales along that series, including pored scales situated posterior to the hypural joint. In fin-ray counts, lower-case Roman numerals indicate unbranched rays, and Arabic numerals indicate branched rays. The last "two" anal-fin rays that are joined at the base were counted as one branched element. Counts for the holotype are indicated in brackets. Measurements were made following the methods outlined in Fink \& Weitzman (1974) and Vari \& Castro (2007) with the addition of the following characters: distance of snout to pectoral-fin origin, and length of longest anal, pectoral and pelvic-fin rays. The descriptions of dentition and stomach contents, and the examination of osteological characters were based on two cleared and counterstained specimens (c\&s) prepared following the method outlined by Taylor \& Van Dyke (1985). Vertebral counts were taken from both radiographs and cleared and counterstained specimens and include the four vertebrae associated with the Weberian apparatus with the terminal element in the ural complex.

Terminology for skeleton follow Weitzman (1962), with some changes proposed in Vari \& Harold (2001) and Vari \& Castro (2004). Photographs were made of cleared and stained material using a stereomicroscope with a digital camera attached.

Abbreviations for institutions are: Field Museum of Natural History, Chicago (FMNH); Laboratório de Biologia e Genética de Peixes, Departamento de Morfologia, Instituto de Biociências, Universidade Estadual Paulista, Botucatu (LBP); Laboratório de Ictiologia de Ribeirão Preto, Universidade de São Paulo, Ribeirão Preto (LIRP); Museu de Ciências e Tecnologia da Pontifícia Universidade Católica do Rio Grande do Sul, Porto Alegre (MCP); Museu Nacional, Universidade Federal do Rio de Janeiro, Rio de Janeiro (MNRJ); Museu de Zoologia da Universidade de São Paulo, São Paulo (MZUSP); Museu de Zoologia da Universidade Estadual de Campinas “Adão José Cardoso”, Campinas (ZUEC); National Museum of Natural History, Smithsonian Institution, Washington, D.C. (USNM). 


\section{Results}

\section{Probolodus Eigenmann, 1911}

Type species. Probolodus heterostomus Eigenmann, 1911

Diagnosis. The genus Probolodus can be diagnosed among the Characidae (sensu Oliveira et al., 2011) by the following exclusive characteristics: only one row of premaxillary, maxillary and dentary teeth (Fig. $1 \mathrm{a}-\mathrm{c}$ ); premaxillary teeth tricuspidate with crown curved outward (Fig. 1a); two cusps of equal size in the maxillary teeth (Fig. 1b); tricuspidate dentary teeth of approximately equal size, followed posteriorly by one or more smaller cuspidated teeth (Fig. 1c), and anterodorsal margin of the maxillary bone overlapping the expanded margin of first infraorbital.

Description. Overall size small (largest examined specimen $110 \mathrm{~mm}$ SL). Body slightly compressed, relatively high, and short or long depending on the species. Greatest body depth in front of insertion of dorsal fin. Small head obtusely rounded anteriorly in lateral view. Eye diameter greater than length of snout. Mouth terminal. Only one teeth row on premaxillary, maxillary and dentary; three or four teeth on premaxilla with three cusps each and with crown curved outward; two to seven teeth on maxilla with two cusps of similar size, first two or three directed outward; four or five anterior tricuspid teeth of dentary larger than remaining cusp being directed out of the mouth. Median cusps of all teeth more developed than lateral cusps. Body covered with cycloid scales from small to large size, and firmly implanted. Lateral line completely pored from supracleithrum to base of caudal-fin. Dorsal-fin consists of two unbranched rays followed by nine branched rays; dorsal-fin origin situated approximately at middle of SL. Pectoral-fin rays with $i+10-13+i$ and pelvic-fin rays with $i+6$ $8+i$. Anal-fin formed by up to five unbranched rays followed by 22-31 branched rays. Adipose-fin well-developed in all examined specimens. Caudal fin forked, with distal margins of lobes obtusely pointed, with $\mathrm{i}+17+\mathrm{i}$ rays. Small scales covering the upper and lower lobes of caudal fin. Hooks present on pelvic and anal fin of sexually mature males.

Distribution. The species of Probolodus occur in a series of tributaries of the coastal basins of southeastern Brazil, from Espírito Santo to São Paulo states (Fig. 2).

\section{Probolodus heterostomus Eigenmann, 1911} Figs. 3-4

Probolodus heterostomus Eigenmann, 1911, monotypic [original description] (type locality: rio Paraíba do Sul basin, Campos, Rio de Janeiro, Brazil). Paratypes [CM 2974, 3, 4864 mm SL]. -Eigenmann, 1915: 3-22 [in part] (type-material). -Jordan, 1920: 538 (citation). -Pearson, 1937: 108 (list). Myers, 1942: 91 [in part] (distribution). -Roberts, 1970: 38489 (dentition and systematic relationships). Géry, 1977: 298, 543, 575-79 (identification key; systematic of Cheirodontinae

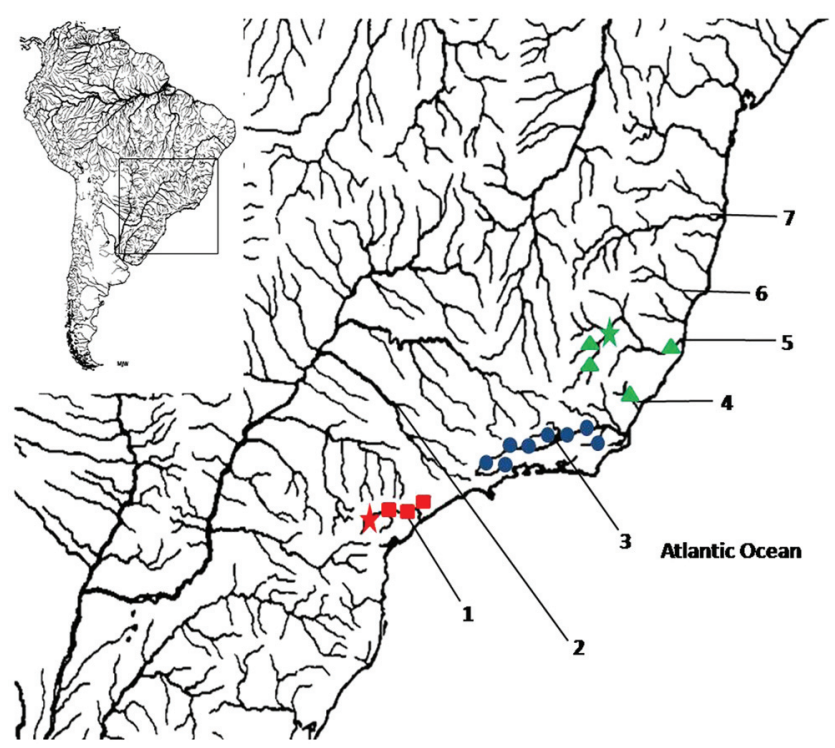

Fig. 2. Geographic distribution of Probolodus oyakawai (squares), $P$. heterostomus (circles), and $P$. sazimai (triangle); star indicates type locality. 1) rio Ribeira de Iguape, 2) rio Tietê, in upper rio Paraná basin, 3) rio Paraíba do Sul, 4) rio Itapemirim, 5) rio Doce, 6) rio Mucuri, 7) rio Jequitinhonha. Symbols may represent more than one locality.
Fig. 1. Probolodus oyakawai, MZUSP 53499, paratype, 64.3 mm SL, teeth: a) Left premaxilla, anterior view; b) Left maxilla, lateral view; c) Left dentary, medial view. Scale bars $=1 \mathrm{~mm}$. 


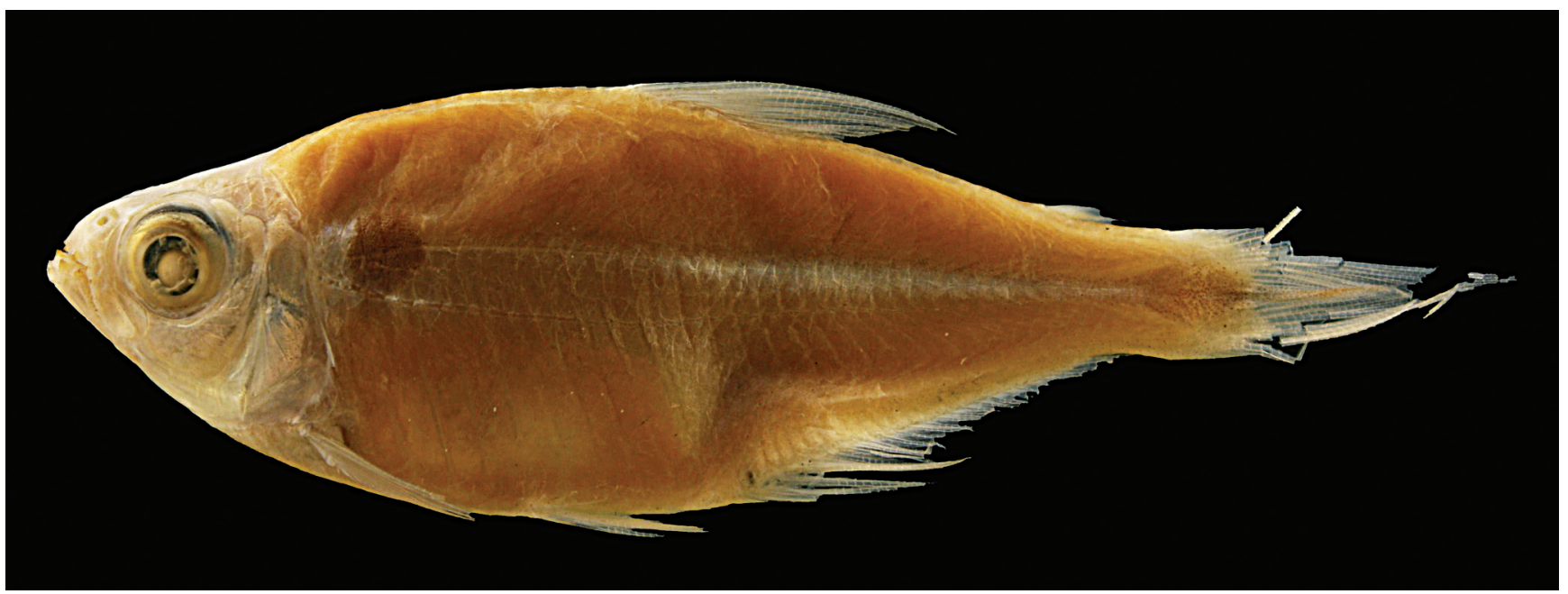

Fig. 3. Probolodus heterostomus, holotype, FMNH 54328, 49.0 mm SL, Brazil, Rio de Janeiro, município de Campos, rio Paraíba do Sul basin.

and comments about dentition - Probolodini tribe). -Sazima, 1977: 510-12 [in part] (distribution; feeding habits). -Géry, 1980: 1-8 (systematic relationships). -Sazima, 1983: 2-13 (lepidophagous habits). -Vari, 1986: 329 (systematic relationships). -Ibarra \& Stewart, 1987: 70 [in part] (typematerial). -Jégu et al., 1991: 773 (dentition and systematic relationships). -Bizerril, 1994: 58, 65 [in part] (distribution and identification key). -L. Malabarba, 1998: 230 (comments). -Lucena, 1998: 23, 30, 32, 33, 34 (dentition and systematic relationships). -Bizerril, 1999: 241 (citation). -Lima et al., 2003: 154 [in part] (type-material; type locality and distribution). -Zanata \& Akama, 2004: 48-49, 52 (comments). -Teixeira et al., 2005: 351 (list). -Pinto et al., 2006: 272, 273 (list). -Nelson, 2006: 157 (comments). -Buckup et al., 2007: 61 [in part] (type locality and distribution). -Menezes et al., 2007: 105 [in part] (type locality; distribution; systematic and ecology). -Mirande, 2007: 20 (systematic relationships). -Mirande, 2009: 580, 583 (systematic relationships). -Azevedo, 2010: 470 (comments). -Mirande, 2010: 385-568 (systematic relationships). -Mirande et al., 2011: 14 (comments). -Oliveira et al., 2011: 21 (systematic relationships). -Mattox \& ToledoPiza, 2012: 847 (dentition and systematic relationships).

Diagnosis. Probolodus heterostomus differs from its two congeners, $P$. oyakawai (new species) and $P$. sazimai (new species) by the following attributes: 45-56 perforated scales on the lateral line (vs. 41-43 and 36-43 perforated scales, respectively); 18-21 scale series around the caudal peduncle (vs. 14-16 scale series around the caudal peduncle); symplectic with bone projection posteroventrally developed (vs. sympletic without bone projection) (Fig. 4a); process extending posteriorly along the dorsal margin of the hyomandibular (vs. hyomandibular with flat margin, without process) (Fig. 4a), and anterior portion of urohyal not bifurcated, with central orifice (vs. anterior portion of urohyal bifurcated) (Fig. 4b).
Description. Morphometrics of holotype and non-type specimens presented in Table 1. Body moderately compressed and deep, less so in individuals of less than $150 \mathrm{~mm} \mathrm{SL}$, greatest body depth within region delimited anteriorly by vertical through insertion of pelvic fin and posteriorly by vertical through origin of dorsal fin. Average body depth variable among population samples, but with broad overlap in ranges among examined samples. Dorsal profile of head distinctly convex from margin of upper lip to vertical through posterior nostril, straight to very slightly convex from latter point to tip of supraoccipital spine. Dorsal profile of body moderately convex from tip of supraoccipital spine to origin of dorsal fin, straight and posteroventrally-slanted along base of dorsal fin, straight to slightly convex from posterior terminus of base of dorsal fin to adipose fin, and slightly concave along caudal peduncle. Broad middorsal ridge present along predorsal region of body, with ridge less obvious anteriorly. Dorsal region of body between posterior terminus of dorsal fin and adipose fin transversely rounded overall, but slightly flattened middorsally in some individuals. Ventral profile of head strongly convex anteriorly from margin of lower lip approximately to vertical through anterior nares, then slightly convex from that point to vertical through posterior margin of eye. Ventral profile of body convex to insertion of pelvic fin, nearly straight but slightly posteroventrally-aligned from that point to origin of anal fin, straight to slightly convex and posterodorsally-slanted along base of anal fin, and slightly concave along caudal peduncle. Prepelvic region of body somewhat flattened transverselly.

Head obtusely rounded anteriorly in lateral profile. Mouth terminal. Upper jaw with maxilla distinctly posteroventrallyangled relative to ventral margin of premaxilla and extending ventral of orbit to point somewhat short of, or reaching, vertical through anterior margin of pupil. Nares of each side of head very close together; anterior opening circular, posterior crescent-shaped with distinct flap between nares. Eye 
relatively large and lacking distinct adipose eyelid. Median fronto-parietal fontanel extending from mesethmoid to supraoccipital spine. Width of fontanel approximately onefifth distance across bony interorbit. Infraorbital series complete with third infraorbital by far largest. All infraorbitals carrying laterosensory canal segments proximate to margin of orbital rim. Supraorbital absent. Branchiostegal rays four. Gill-rakers long and setiform; 10-12+1+6-9 rakers present on first gill-arch.

Teeth on premaxillary, maxillary, and dentary in one row. Premaxilla with three (159) or four (1) teeth [three] somewhat directed outward; each tooth with three points in angles of a nearly isosceles triangle; middle point, which is also the anterior one, much larger. Maxilla with two to five (commonly four) teeth [four] with two cusps of similar size, first two or three directed outward. Dentary with four large teeth, first three directed outward, fourth, and one or more smaller ones following it, directed upward; larger teeth of lower jaw heavy, conical, with a minute cusp on each side; in overall, dentary has five to seven (commonly five) tricuspidate or biscupidate teeth [five].

Scales cycloid, relatively small, firmly implanted. Lateral line decurved anteriorly approximately to vertical through origin of dorsal fin, then slightly posterodorsally-angled to caudal peduncle, and then running horizontally to terminus of scale series. Lateral line completely pored from supracleithrum to base of caudal fin and followed posteriorly by ossified tubular extension running along lateral margin of membrane joining middle rays of caudal fin. Lateral-line scales 45 (18), 46 (10), 47 (10), 48 (52), 49 (8), 50 (26), 51 (7), 52 (4), 53 (9), 54 (4), 55 (4), or 56 (3) [47]; scales in transverse series from origin of dorsal fin to lateral line 8 (7), 9 (108), or 10 (42) [9]; scales in transverse series from insertion of pelvic fin to lateral line 7 (75) or 8 (82) [8]; scales in transverse series from origin of anal fin to lateral line 7 (1), 8 (38), 9 (117), or 10 (1) [9]; scales along middorsal line between tip of supraoccipital process and origin of dorsal fin 12 (80), 13 (69), or 14 (6) [12]; scales along middorsal line between posterior termination of base of dorsal fin and adipose fin 14 (3), 15 (47), 16 (87), or 17 (20) [14]; horizontal scale rows around caudal peduncle 18 (94), 19 (41), 20 (17), or 21 (3) [20]. Vertebrae $34(n=13)$ or $35(n=23)$.

Dorsal-fin rays ii,9 (159) [ii,9]. Anal-fin rays iii (2), iv (43) or v (114), 23 (2), 24 (6), 25 (14), 26 (43), 27 (45), 28 (34), 29 (12), 30 (2), or 31 (1) [iii,26]. Pectoral-fin rays i,10,i (2), i,11 (9), i,11,i (54), i,12 (68), i,12,i (18), or i,13 (6) [i,12]. Pelvic-fin rays i,6 (3), i,6,i (2), i,7 (153), or i,8 (1) [i,7]. Principal caudal-fin rays i,17,i (159).

Dorsal-fin margin distally rounded to slightly truncate; first unbranched ray approximately $40-50 \%$ length of second unbranched ray. Dorsal-fin origin situated along vertical located approximately at middle of SL. Origin of adipose fin located slightly anterior of vertical through posterior terminus of base of anal fin. Profile of adpressed pectoral fin distinctly acute. Tip of pectoral fin extending approximately to vertical through insertion of pelvic fin. Profile of expanded pelvic fin pointed, with first branched ray either longest in fin or subequal

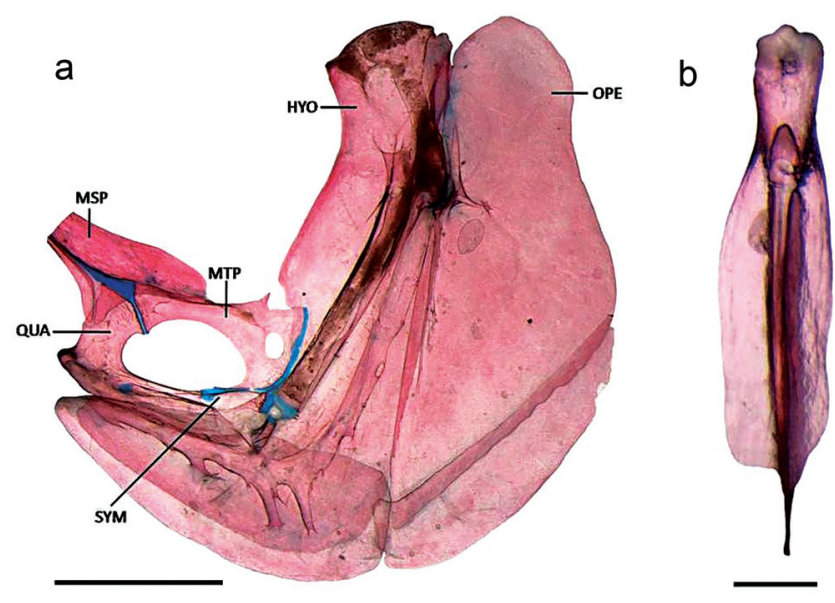

Fig. 4. Suspensorium, lateral view (a) and of the urohyal, dorsal view (b) of Probolodus heterostomus, LIRP 6296, $70.7 \mathrm{~mm} \mathrm{SL}$. HYO: hyomandibula, MSP: mesopterygoid, MTP: metapterygoid, OPE: opercle, QUA: quadrate, SYM: symplectic. Scale bars $=1 \mathrm{~mm}$.

to unbranched ray. Insertion of pelvic fin located distinctly anterior to vertical through origin of dorsal fin. Tip of adpressed pelvic fin extending approximately to vertical through insertion of anal fin. Some larger, apparently male, specimens with posteriorly-directed hooks along posterior margins of second through seventh pelvic-fin rays; hooks rarely also present on first ray. Hooks limited to posterior branch of hook-bearing rays. Each hook-bearing segment typically with one hook, although two hooks occasionally present on some segments. Distal margin of anal fin slightly concave in which fourth or fifth unbranched and first and second branched rays longest and subequal or first through third branched rays longest with subsequent branched rays gradually decreasing in length. Some larger, apparently male, individuals with hooks present on various rays gradually of anal fin. Hooks most often arise along posterior margin of posterior branch of second through seventh branched rays. Hooks extending onto unbranched segments of some rays. Caudal fin forked, with distal margins of lobes obtusely pointed.

Color in alcohol. Overall ground color of body in specimens fixed in formalin yellowish brown. Guanine remaining on lateral and ventral portions of head and on ventral and, to a variable degree, lateral surfaces of body. Snout and dorsal portion of head relatively dark. Middorsal and immediately adjoining portions of body relatively dark. Distinct, wedge-shaped, ventrally-attenuated humeral blotch with irregular margins extending from approximately five scales dorsal of lateral line to about two scales ventral of lateral line. Pigmentation of humeral blotch typically most intense in region dorsal of lateral line, with pigmentation of remaining ventral portion of blotch variably lighter, but still quite obvious. Dark midlateral pigmentation more conspicuous on portion of body beginning 
at vertical through anterior portion of dorsal fin, with stripe widening posteriorly on caudal peduncle into distinct, horizontally-elongate, ovoid blotch. Pigmentation of blotch more intense than that of remainder of stripe. Chromatophores of dorsal portion are concentrated at the base and middle region of the scales, its margins being free of chromatophores. Region below the lateral line decreases the concentration of chromatophores, and, between the anal fin and caudal peduncle, sparse chromatophores are present in greater proportion.

Dorsal, anal, and caudal fins with interradial membranes covered by small dark chromatophores, with chromatophores often more concentrated proximate to margins of fin rays. Dark pigmentation on caudal fin more intense along middle fin-rays in most specimens and forming stripe variably continuous anteriorly with midlateral dark blotch on caudal peduncle. Anal fin with unbranched rays and all branched rays pigmented. Distal half of remainder of fin with dark chromatophores in all individuals, with fields of chromatophores extending nearly to base of fin membranes. Adipose fin lightly colored overall, but often freckled with small dark spots. Pectoral and pelvic fins with small, dark spots located both along fin-ray margins.

Distribution. Probolodus heterostomus is known to occur in the tributaries of rio Paraíba do Sul basin, southeastern Brazil (Fig. 2).

Ecological notes. Probolodus heterostomus was studied by Sazima (1977; 1983) because of its habit of tearing off and eating scales of other fishes. Pieces of leaves, insects and scales were observed in the mouth of many specimens preserved in alcohol (MZUSP 44110, 5, 40.2-46.7 mm SL; MZUSP 7904, 6, 42.3-56.6 mm SL). However, ctenoid and many cycloid fish scales were found in the stomach contents and between gill rakers of the cleared and stained specimens (LIRP 6296, 2, 72.7-88.5 mm SL; ZUEC 5498, 2, 77.3-100.8 mm SL).

Remarks. Roberts (1970) examining stomach contents of some lepidophagous characids, such as Catoprion, Exodon, Roeboides, and Roeboexodon, was the first author to observe a large number of scales in the stomachs of specimens of Probolodus heterostomus and commented on the absence, until then, of knowledge about the relationships among the lepidophagous genera aforementioned (see more details about the lepidophagous taxa in Sazima, 1977; Géry, 1980; Sazima \& Uieda, 1980; Sazima \& Machado, 1982; Sazima, 1983; Vari, 1986; Janovetz, 2005). Still, Roberts (1970) considered the genus $P$. heterostomus very similar to the tetras of the genus Astyanax.

Therefore, Géry (1977) based in Eigenmann (1911, 1915) and Roberts (1970), considered P. heterostomus morphologically very similar to the tetras of the genus Astyanax, especially A. fasciatus, but both with different dentitions. According to the cited author, the tricuspidate teeth of $P$. heterostomus are few in number and directed outward, especially on the prominent dentary, enabling it to remove rows of scales of other fishes, possibly from the bottom up. However, Sazima (1977) suggested that A. fasciatus is the main prey of $P$. heterostomus, which are externally very similar and sympatric species occurring in the drainage of the rio Paraíba do Sul. In addition, Sazima (1977; 1983) hypothesized that the similarity between these two genera is a form of disguise or aggressive mimicry.

Material examined: Holotype. FMNH 54328 [ex CM 2973], 49.0 mm SL, Brazil, Rio de Janeiro, município de Campos, rio Paraíba do Sul basin, 13 Jun 1908, J. D. Haseman. Paratypes. FMNH 54329 [ex CM 2974], 2, 36-38 mm SL, Brazil, Rio de Janeiro, município de Campos, rio Paraíba do Sul basin, 13 Jun 1908, J. D. Haseman. Non-type specimens. All specimens from Brazil. São Paulo State: LIRP 6296, 2, 72.7-88.5 mm SL (2 c\&s), município de Guararema, rio Paraíbuna basin, 2324'59”'S 4602'59'”'W; MZUSP 14743, 1, 49.9 mm SL, município de Jacareí,

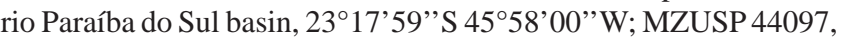
14, 38.8-62.5 mm SL, município de Natividade da Serra, rio Paraíbuna

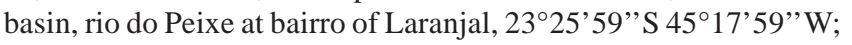
MZUSP 44108, 1, 55.3 mm SL, município de Redenção da Serra, rio Paraíbuna basin, rio Paraitinga between the Mineiros bridge and sítio of Mr. Ismael, 23¹5'59”'S 45³2'59’'W; MZUSP 44110, 20, 30.5-49.3 mm SL, município de Natividade da Serra, rio Paraíbuna basin, unnamed stream at bairro of Volta Comprida, $5 \mathrm{~km}$ after the

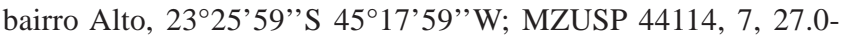
58.5 mm SL, município de Natividade da Serra, rio Paraíbuna basin, unnamed stream at bairro of Volta Comprida, $5 \mathrm{~km}$ after the bairro Alto, 2325'59"S 45¹7’59"W; MZUSP 45920, 1, 58.4 mm SL, município de Guararema, rio Paraíbuna basin, rio Itapeti, 2324'59"S 4602’59"W; MZUSP 45922,15, 32.3-47.3 mm SL, município de Paraíbuna, rio Paraíbuna basin, unnamed stream at bairro of Volta

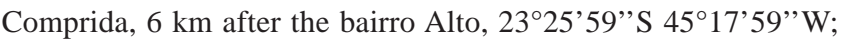
MZUSP 7904, 30, 40.2-58.8 mm SL, município de Santa Branca, rio Paraíba do Sul basin, represa de Santa Branca, $23^{\circ} 21^{\prime}$ S 4549'59' 'W; MZUSP 93978, 1, 52.8 mm SL, município de

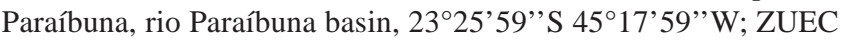
2239, 1, 63.4 mm SL, município de Jacareí, rio Paraíba do Sul basin, 23¹8’S 4557’35”'W; ZUEC 2240, 1, 70.4 mm SL, município de Jacareí, rio Paraíba do Sul basin, 2318'S 4557’35’'W; ZUEC 2241, 1, 62.7 mm SL, município de Jacareí, rio Paraíba do Sul basin, 23¹8'S 4557’35’'W; ZUEC 2242, 1, 61.4 mm SL, município de Jacareí, rio Paraíba do Sul basin, 2318'S 4557’35’”W; ZUEC 2243, 1, $57.5 \mathrm{~mm}$ SL, município de Jacareí, rio Paraíba do Sul basin, 23¹8'S 4557’35’'W; ZUEC 2244, 1, 57.1 mm SL, município de Jacareí, rio Paraíba do Sul basin, 2318'S 4557’35’'W; ZUEC 2245, 1, 55.7 mm SL, município de Jacareí, rio Paraíba do Sul basin, 23¹8’S 4557’35’'W; ZUEC 2246, 1, 53.7 mm SL, município de Jacareí, rio Paraíba do Sul basin, 2318’S 4557’35’'W; ZUEC 2247, 1, $56.8 \mathrm{~mm}$ SL, município de Jacareí, rio Paraíba do Sul basin, 23¹8'S 4557'35'”'W; ZUEC 2248, 1, 57.9 mm SL, município de Jacareí, rio Paraíba do Sul basin, 2318'S 4557’35”'W; ZUEC 2249, 1, $49.4 \mathrm{~mm}$ SL, município de Jacareí, rio Paraíba do Sul basin, 23¹8'S 4557’35’'W; ZUEC 2250, 1, 49.0 mm SL, município de Jacareí, rio Paraíba do Sul basin, 2318’S 4557’35”'W; ZUEC 2251, 1, $50.8 \mathrm{~mm}$ SL, município de Jacareí, rio Paraíba do Sul basin, 23¹8'S 4557'35'”'W; ZUEC 2252, 1, 51.2 mm SL, município de Jacareí, rio Paraíba do Sul basin, 2318’S 4557’35’'W; ZUEC 3559, 3, 49.1-83.7 mm SL, município de Paraíbuna, rio Paraíbuna basin, 23²2'48's 45³9'35”'W; ZUEC 4086, 4, 61.5-78.4 mm SL, 
município de Paraíbuna, rio Paraíbuna basin, 2322'48's 45³9'35'’W; ZUEC 4603, 2, 66.2-71.9 mm SL, município de

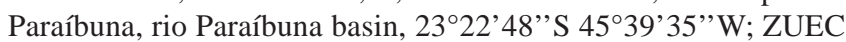
4667, 2, 16.3-17.1 mm SL, município de Jacareí, rio Paraíba do Sul basin, 23¹8'S 4557'35'”W; ZUEC 4823, 1, 71.3 mm SL, município

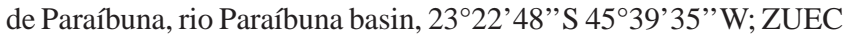
4824, 1, 70.8 mm SL, município de Paraíbuna, rio Paraíbuna basin, rio Parateí, 2322’48'”S 45³9'35'”W; ZUEC 5501, 1, 26.5 mm SL, município de Jacareí, rio Paraíba do Sul basin, 2318’S 4557’35"W; ZUEC 5498, 17, 77.3-100.8 mm SL (2 c\&s), município de Paraíbuna, rio Paraíbuna basin, 2322'48'”S 45³9'35”'W. Rio de Janeiro State: MNRJ 10942, 3, 35.5-62.8 mm SL, município de Itatiaia, rio Paraíba do Sul basin, ribeirão Santo Antônio, vale do Paraíba, 22²9’29"S 44³3’33"W; MNRJ 13864, 5, 32.2-83.8 mm SL, município de Silva Jardim/Araruama, rio Paraíba do Sul basin, Jaturnaíba small lake, 22³9’03"S 42²4’20"W; MNRJ 15382, 1, 94.8 mm SL, município de Três Rios, rio Paraíbuna basin, left hand

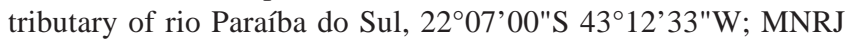
17874, 17918, 4, 72.2-89.4 mm SL, município de Barra Mansa, rio Paraíba do Sul basin, rio do Turvo, 22³2'38"S 44¹0’15"W; MNRJ 19251, 10, 35.2-49.6 mm SL, rio Paraíba do Sul basin, rio Pirineus or Crubixais (left hand tributary of rio São José), under bridge near

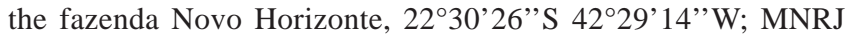
25988, 1, 47.9 mm SL, rio Paraíba do Sul, unnamed small stream near of Quatis, approximately $7 \mathrm{~km}$, left hand tributary of rio Paraíba do Sul, $22^{\circ} 24^{\prime} 26^{\prime \prime S} 44^{\circ} 15^{\prime} 29^{\prime \prime} \mathrm{W}$.

\section{Probolodus oyakawai, new species} Figs. 1; 5-6

Probolodus heterostomus, Eigenmann, 1911: 164 [in part], paratypes. -Eigenmann, 1915: 20-22 [in part]. Paratypes [CM 2975, 2, 78-81 mm SL]: P. heterostomus (Brazil, São Paulo, Iporanga, rio Ribeira de Iguape basin). -Sazima, 1977: 510, 512 [in part] (distribution and ecology). -Bizerril, 1994: 58, 65 [in part] (distribution and identification key). -Bizerril \& Lima, 2000: 103-110 (list). -Lima et al., 2003: 154 [in part] (type-material, type locality and distribution). Oyakawa et al., 2006: 45, 156-157 [in part] (distribution, citation, and biology). -Buckup et al., 2007: 61 [in part] (type locality and distribution). -Menezes et al., 2007: 105 [in part] (type locality; distribution; systematic and ecology).

Holotype. MZUSP 114013, 40.6 mm SL, Brazil, São Paulo, município de Iporanga, rio Ribeira de Iguape basin, 24³4'22"S 48³3’34"W, 20 Apr 1998, O. T. Oyakawa, V. Garutti, M. T. Piza Ragazzo \& C. Ragazzo.

Paratypes. All specimens from Brazil. São Paulo State: FMNH 54330 [CM 2975], 2, 61-63 mm SL, município de Iporanga, rio Ribeira de Iguape basin; MZUSP 35928, 2, 43.6-52.1 mm SL, município de Miracatú, Jaraçatiá, rio Ribeira de Iguape basin, rio

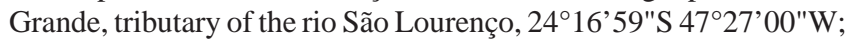
MZUSP 38809, 3, 44.7-58.5 mm SL, município de Iguape, rio Ribeira de Iguape basin, rio do Espraiado, southern limit of the Reserva

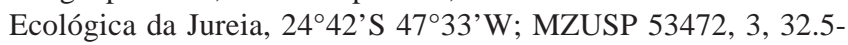
$37.9 \mathrm{~mm}$ SL, município de Pariquera-Açu, rio Ribeira de Iguape basin, rio Jacupiranga, irrigation canal of the CODASP (CEDAVAL), km 460 of the BR-116, 24³6'31"S 4753'48"W; MZUSP 53499, 12, 21.4-64.3 mm SL, município de Jacupiranga, rio Ribeira de Iguape basin, stream that goes through the BR-116, km 470, near the town of Jacupiranga, 2439'S 4758'00"W (2 c\&s, 31.7-64.3 mm SL); MZUSP 53549, 4, 34.6-41.8 mm SL, município de Iporanga, rio Ribeira de Iguape basin, tributary of the rio Betari on the road to the Santana cave, $5 \mathrm{~km}$ from the town of Iporanga, 24³5’00"S 48³6’59"W; MZUSP 55006, 4, 34.6-37.9 mm SL, município de Iporanga, rio Ribeira de Iguape basin, mouth of the rio Iporanga, 24³4’22"S 48³3’34"W (1 c\&s, 37.9 mm SL), collected with holotype; MZUSP 64774, 1, 56.5 mm SL, município de Sete Barras, Ribeira de Iguape basin, mouth of the rio Saibadela, at the limits between the parks Intervales and Carlos Botelho, 24¹4'14"S 4803’09"W; MZUSP 8003, 2, 31.5-58.5 mm SL, município de Iguape, rio Ribeira de Iguape basin, rio Branco da Serra, tributary of the rio Espraiado, $24^{\circ} 24^{\prime} 38^{\prime \prime} S$ 47²5'36"W; MZUSP 84674, 4, 35.2-39.8 mm SL, município de Sete Barras, rio Ribeira de Iguape basin, fazenda Brasban, rio Ipiranga, 24¹0’46"S 4751’14"W; ZUEC 1693, 1, 43.6 mm SL, município de Iguape, rio Ribeira de Iguape basin, tributary of the rio Despraiado, 24²'01"S 47³2'58"W; ZUEC 1694, 1, 48.8 mm SL, município de Iguape, rio Ribeira de Iguape basin, tributary of the rio Despraiado, $24^{\circ} 42^{\prime} 01^{\prime \prime S}$ 47³2'58"W.

Diagnosis. Probolodus oyakawai differs from its two congeners, $P$. heterostomus and $P$. sazimai (new species) by the following characteristics: the base of the large epural not leaning against the urostyle bone (vs. the base of the large epural in contact, not fused the urostyle) (Fig. 6a); first and second infraorbitals contacting but not overlapping (vs. relationship with overlapping or leaning against) (Fig. 6b); posterior portion of the maxilla extended in relation to median portion (vs. posterior portion of the same width than median portion) (Fig. 1b); anterior extension of nasal reaching the lateral projection of mesethmoid (vs. outpacing the end of the projection of mesethmoid). It may be further separated from $P$. heterostomus by three attributes: 41-43 perforated scales on the lateral line (vs. 45-56 perforated scales); 14-16 scale series around the caudal peduncle (vs. 18-21 scale series around the caudal peduncle); body relatively shorter, with 33-34 totals vertebrae (vs. 34-35 totals vertebrae).

Description. Morphometrics of types presented in Table 1. Body moderately compressed and deep, less so in individuals of less than $150 \mathrm{~mm} \mathrm{SL}$, greatest body depth within region delimited anteriorly by vertical through insertion of pelvic fin and posteriorly by vertical through origin of dorsal fin. Average body depth variable among population samples, but with broad overlap in ranges among examined samples. Dorsal profile of head distinctly convex from margin of upper lip to vertical through posterior nostril, straight to very slightly convex from latter point to tip of supraoccipital spine. Dorsal profile of body moderately convex from tip of supraoccipital spine to origin of dorsal fin, straight and posteroventrallyslanted along base of dorsal fin, straight to slightly convex from posterior terminus of base of dorsal fin to adipose fin, and slightly concave along caudal peduncle. Broad middorsal ridge present along predorsal region of body, with ridge less 


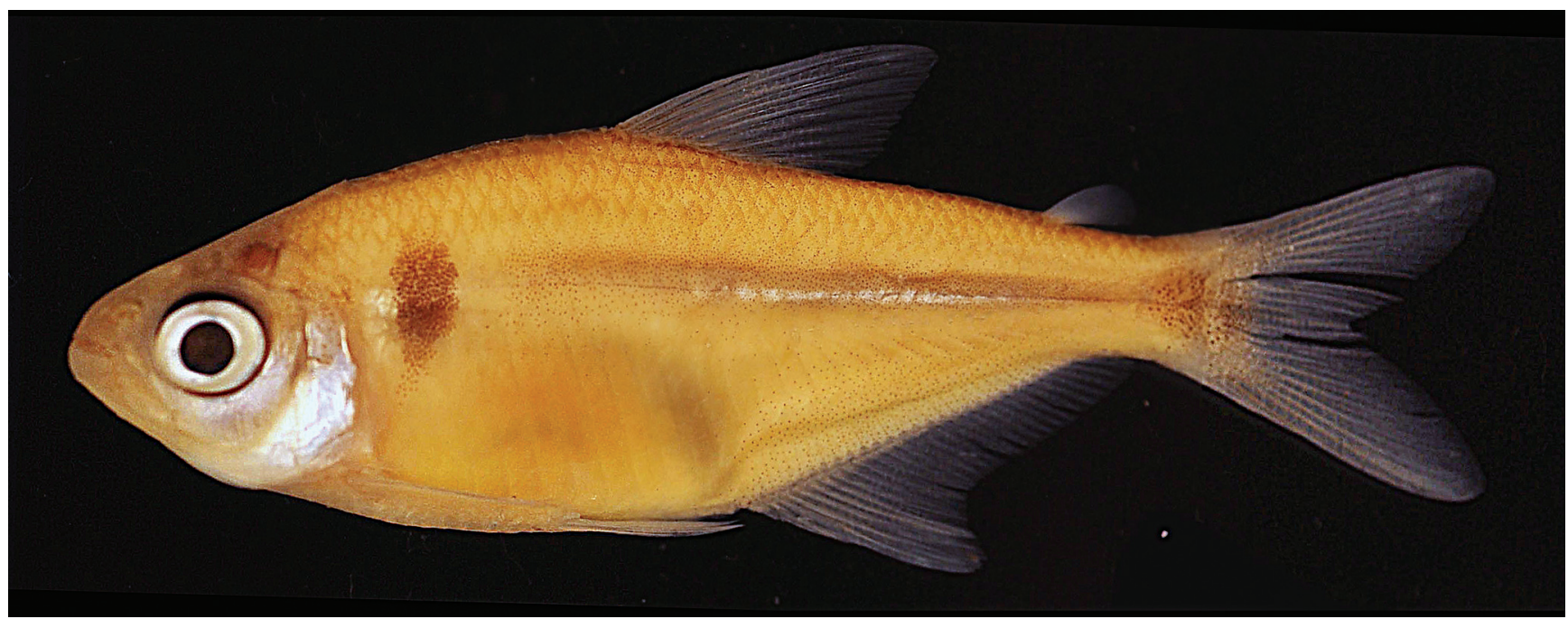

Fig. 5. Probolodus oyakawai, holotype, MZUSP 114013, 40.6 mm SL, Brazil, São Paulo, município de Iporanga, rio Ribeira de Iguape basin.

obvious anteriorly. Dorsal region of body between posterior terminus of dorsal fin and adipose fin transversely rounded overall, but slightly flattened middorsally in some individuals. Ventral profile of head sligtly convex anteriorly from margin of lower lip approximately to vertical through anterior nares, then straight from that point to vertical through posterior margin of eye. Ventral profile of body convex to insertion of pelvic fin, nearly straight but slightly posteroventrally-aligned from that point to origin of anal fin, straight to slightly convex and posterodorsally-slanted along base of anal fin, and slightly concave along caudal peduncle. Prepelvic region of body somewhat flattened transverselly.

Head obtusely rounded anteriorly in lateral profile. Mouth terminal. Upper jaw with maxilla distinctly posteroventrallyangled relative to ventral margin of premaxilla and extending ventral of orbit to point somewhat short of, or reaching, vertical through anterior margin of pupil. Nares of each side of head very close together; anterior opening circular, posterior crescent-shaped with distinct flap between nares. Eye relatively large and lacking distinct adipose eyelid. Median fronto-parietal fontanel extending from mesethmoid to supraoccipital spine. Width of fontanel approximately onefifth distance across bony interorbit. Infraorbital series complete with third infraorbital by far largest. All infraorbitals carrying laterosensory canal segments proximate to margin of orbital rim. Supraorbital absent. Branchiostegal rays four. Gill-rakers long and setiform; $11-13+1+7-8$ rakers present on first gill-arch.

Teeth on premaxillary, maxillary, and dentary in one row. Premaxilla with three (37) teeth [three] somewhat directed outward; each tooth with three points in angles of a nearly isosceles triangle; middle point, which is also the anterior one, much larger. Maxilla with two to seven (commonly four) teeth [four] with two cusps of similar size, first two or three directed outward. Dentary, mostly, with five large teeth, first three directed outward, fourth and fifth tricuspidate, and one or more smaller ones following it, directed upward; larger teeth of lower jaw heavy, conical, with a minute cusp on each side; in overall, dentary has five to seven (commonly six) tricuspidate or biscupidate teeth [six].

Scales cycloid, relatively small, and firmly implanted. Lateral line decurved anteriorly approximately to vertical through origin of dorsal fin, then slightly posterodorsallyangled to caudal peduncle, and then running horizontally to terminus of scale series. Lateral line completely pored from supracleithrum to base of caudal fin and followed posteriorly by assified tubular extension running along lateral margin of membrane joining middle rays of caudal fin. Lateral-line scales 41 (2), 42 (29), or 43 (3) [42]; scales in transverse series from origin of dorsal fin to lateral line 7 (5), 8 (29), or 9 (1) [8]; scales in transverse series from insertion of pelvic fin to lateral line 7 (33) or 8 (1) [7]; scales in transverse series from origin of anal fin to lateral line 7 (24) or 8 (11) [7]; scales along middorsal line between tip of supraoccipital process and origin of dorsal fin 12 (35) or 13 (2) [12]; scales along middorsal line between posterior termination of base of dorsal fin and adipose fin 13 (2), 14 (7), 15 (27), or 16 (1) [15]; horizontal scale rows around caudal peduncle $14(25)$ or $16(7)$ [14]. Vertebrae $33(n=4)$ or 34 (n=19) [34].

Dorsal-fin rays ii,9 (37) [ii,9]. Anal-fin rays iv (12) or v (25), 22 (1), 23 (2), 24 (7), 25 (18), 26 (6), or 27 (3) [v,27]. Pectoral-fin rays i,10 (1), i,10,i (6), i,11 (18), i,11,i (8), or i,12 (4) [i,11,i]. Pelvic-fin rays i,7 (31), i,7,i (5) [i,7]. Principal caudal-fin rays $\mathrm{i}, 17, \mathrm{i}(37)[\mathrm{i}, 17, \mathrm{i}]$.

Dorsal-fin margin distally rounded to slightly truncate; first unbranched ray approximately 40-50\% length of second unbranched ray. Dorsal-fin origin situated along vertical located approximately at middle of SL. Origin of adipose fin located slightly anterior of vertical through posterior terminus of base of anal fin. Profile of adpressed pectoral fin distinctly acute. Tip of pectoral fin extending approximately to vertical through insertion of pelvic fin. Profile of expanded pelvic fin pointed, 
with first branched ray either longest in fin or subequal to unbranched ray. Insertion of pelvic fin located distinctly anterior to vertical through origin of dorsal fin. Tip of adpressed pelvic fin extending approximately to vertical through insertion of anal fin. Some larger, apparently male, specimens with posteriorly-directed hooks along posterior margins of second through seventh pelvic-fin rays; hooks rarely also present on first ray. Hooks limited to posterior branch of hook-bearing rays. Each hook-bearing segment typically with one hook, although two hooks occasionally present on some segments. Distal margin of anal fin slightly concave in which fourth or fifth unbranched and first and second branched rays longest and subequal or first through third branched rays longest with subsequent branched rays gradually decreasing in length. Some larger, apparently male, individuals with hooks present on various rays gradually of anal fin. Hooks most often arise along posterior margin of posterior branch of second through seventh branched rays. Hooks extending onto unbranched segments of some rays. Caudal fin forked, with distal margins of lobes obtusely pointed.

Color in alcohol. Overall ground color of body in specimens fixed in formalin yellowish brown. Guanine remaining on lateral and ventral portions of head and on ventral and, to a variable degree, lateral surfaces of body. Snout and dorsal portion of head relatively dark. Middorsal and immediately adjoining portions of body relatively dark. Distinct, wedge-shaped, ventrally-attenuated humeral blotch with irregular margins extending from approximately five scales dorsal of lateral line to about two scales ventral of lateral line. Pigmentation of humeral blotch typically most intense in region dorsal of lateral line, with pigmentation of remaining ventral portion of blotch variably lighter, but still quite obvious. Dark midlateral pigmentation more conspicuous on portion of body beginning at vertical through anterior portion of dorsal fin, with stripe widening posteriorly on caudal peduncle into distinct, horizontally-elongate, ovoid blotch. Pigmentation of blotch more intense than that of remainder of stripe. Chromatophores of dorsal portion are concentrated at the base and middle region of the scales, its margins being free of chromatophores. Region below the lateral line decreases the concentration of chromatophores, and, between the anal fin and caudal peduncle, sparse chromatophores are present in greater proportion.

Dorsal, anal, and caudal fins with interradial membranes covered by small dark chromatophores, with chromatophores often more concentrated proximate to margins of fin rays. Dark pigmentation on caudal fin more intense along middle fin-rays in most specimens and forming stripe variably continuous anteriorly with midlateral dark blotch on caudal peduncle. Anal fin with unbranched rays and all branched rays pigmented. Distal half of remainder of fin with dark chromatophores in all individuals, with fields of chromatophores extending nearly to base of fin membranes. Adipose fin lightly colored overall, but often freckled with small dark spots. Pectoral and pelvic fins with small, dark spots located both along fin-ray margins.

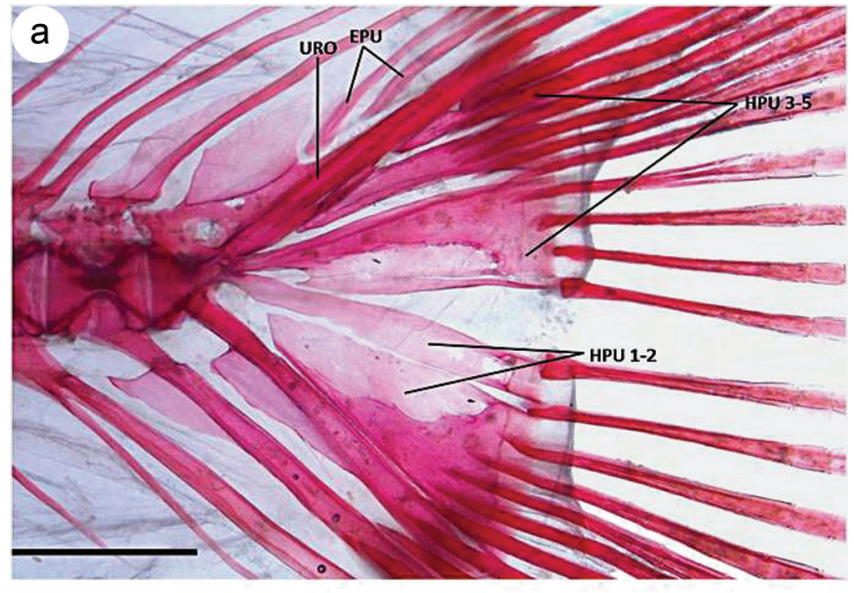

b

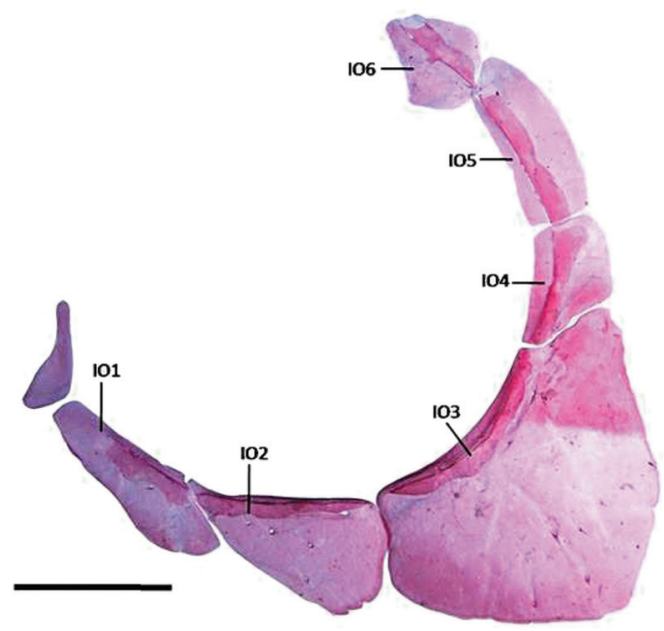

Fig. 6. Probolodus oyakawai: a) caudal skeleton, MZUSP 55006, paratype, $36.8 \mathrm{~mm}$ SL, lateral view. EPU: epurals, HPU 1-5: hypurals, URO: urostyle; b) infraorbital series, MZUSP 53499, paratype, $64.3 \mathrm{~mm}$ SL, lateral view. IO 1-6: first to sixth infraorbitals. Scale bars $=1 \mathrm{~mm}$.

Distribution. Probolodus oyakawai is known to occur in the rio Ribeira de Iguape basin, southeastern Brazil (Fig. 2).

Ecological notes. Ctenoid and cycloid fish scales were observed in the stomach contents of three $P$. oyakawai specimens (MZUSP 53499, 2, 31.7-64.3 mm SL; MZUSP 55006, 1, $37.9 \mathrm{~mm} \mathrm{SL}$ ). No other item could be identified, possibly due to their advanced state of decomposition.

Etymology. The species name, oyakawai, is in honor of Osvaldo T. Oyakawa from MZUSP, the collector of many of the specimens that served as the basis of this paper, in appreciation of his major contributions to our knowledge of the fishes of the rio Ribeira de Iguape basin.

Remarks. Probolodus oyakawai has been previously cited as $P$. heterostomus by various authors who have studied specimens collected in the rio Ribeira de Iguape basin (see 


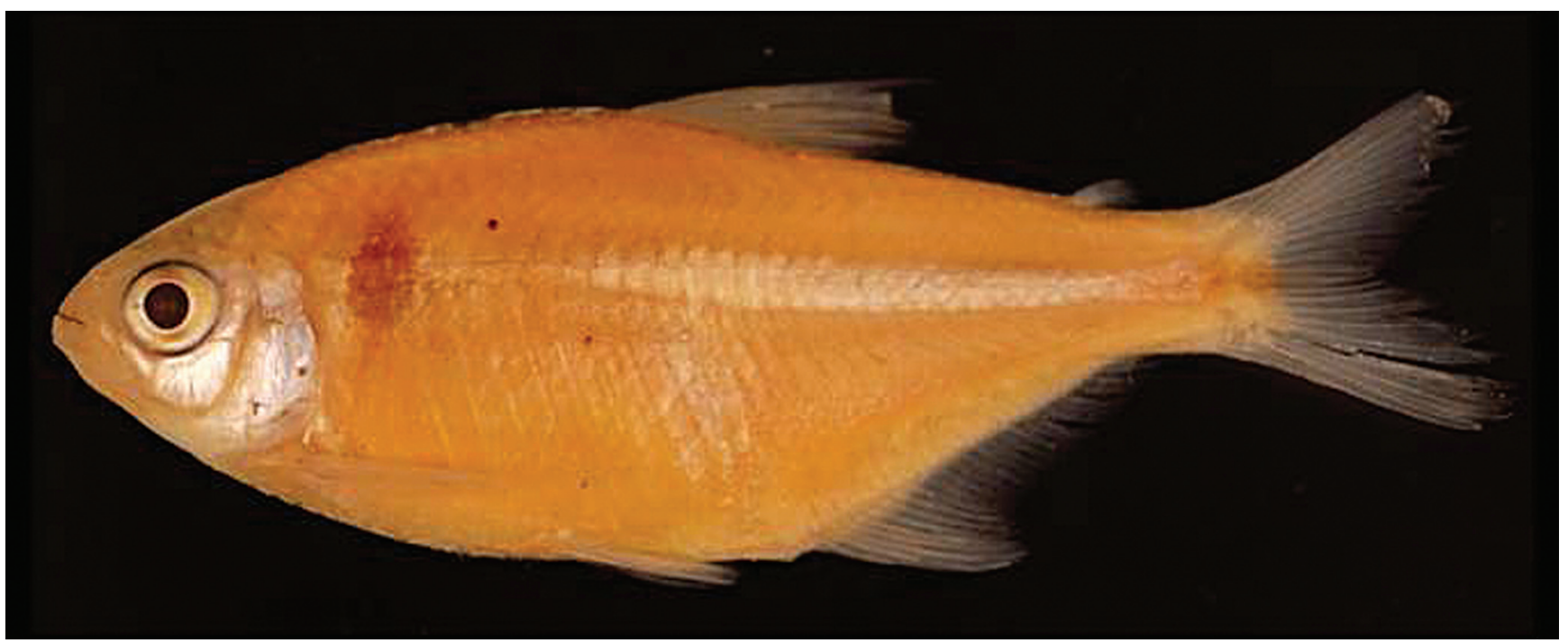

Fig. 7. Probolodus sazimai, holotype, MCP 47870, 56.7 mm SL, Brazil, Minas Gerais, município de Ipatinga, rio Taquaruçu, rio Doce basin.

synonymy). However, as shown on the item "Ecological notes", P. oyakawai also shows preference by fish scales. Thus, as hypothesized by Sazima (1977), Astyanax fasciatus is not found over the entire range of Probolodus, being probable that in other drainages there is an association with other similar species of Astyanax. In the rio Ribeira de Iguape basin, A. ribeirae is a likely candidate, as Deuterodon iguape, which also have the general appearance of Astyanax (Sazima, 1977; Oyakawa et al., 2006).

\section{Probolodus sazimai, new species}

Figs. 7-9

Probolodus heterostomus, Eigenmann, 1911: 164 [in part]. Eigenmann, 1915: 20-22 [in part]. -Sazima, 1977: 510 [in part] (distribution). -Bizerril, 1994: 58, 65 [in part] (distribution and identification key). -Lima et al., 2003: 154 [in part] (type-material, type locality and distribution). -Oyakawa et al., 2006: 156 [in part] (distribution). -Buckup et al., 2007: 61 [in part] (type locality and distribution). Menezes et al., 2007: 105 [in part] (type locality; distribution; systematic and ecology).

Holotype. MCP 47870, 56.7 mm SL, Brazil, Minas Gerais, município de Ipatinga, rio Taquaruçu, tributary of rio Doce basin, 19²7’S 42²8’59"W, 09 Nov 1989, C. Lucena, E. Pereira, J. Pezzi \& P. Azevedo.

Paratypes. All specimens from Brazil. Espírito Santo State: MZUSP 27577, 1, 46.5 mm SL, rio Itapemirim basin, fazenda Boa Esperança between the towns of Pacotuba and Coutinho, 2045'S 41¹8'59"W; MZUSP 79668, 1, 50.7 mm SL, município de Linhares, rio Doce basin, Juparanã pond, 19²3'28"S 4004'20"W. Minas Gerais State: LBP 3433, 1, $45.1 \mathrm{~mm} \mathrm{SL}$, rio Doce drainage basin, rio Matipó, 20¹8’09"S 42²0’04"W; MCP 13813, 4, 36.8-54.4 mm SL, município de Ipatinga, rio Doce basin, rio Taquaruçu along road BR-381, 19²7’'S 42²8'59"W (1 c\&s, 43.5 mm SL), collected with holotype; MNRJ 17120, 1, 36.7 mm SL, município de Chiador, córrego da Tocaia, left hand tributary of rio Paraíba do Sul, 2200’10"S, 4303’28"W; MZUSP 41725, 3, 40.7-51.7 mm SL, município de Ipatinga, rio Doce basin, rio Taquaruçu along road BR-381, 19³9’59"S, 42²6’00"W.

Diagnosis. Probolodus sazimai differs from its two congeners, $P$. heterostomus e P. oyakawai (new species) by the following characteristics: six transverse series of scales from insertion of pelvic fin to lateral line (vs. seven/eight); 12 scales along middorsal line between posterior termination of base of dorsal fin and adipose fin (vs. 14-17 and 13-16, respectively); presence of two pairs of uroneurals (vs. absent or just one pair) (Fig. 8a); anterior margin of the hypurals 2 and 3 in contact, not fused (vs. hypurals 2 and 3 distinctly separate) (Fig. 8a); end piece or stay of the dorsal fin leaning against or fused in the last pterygiophore ( $v s$. somewhat removed of the last pterygiophore) (Fig. 8b); fourth basibranchial completely cartilaginous (vs. ossified) (Fig. 9a); dorsal margin of the opercle more elevated than the hyomandibular (vs. opercle and hyomandibular practically aligned) (Fig. 9b); anteromedially projection of the mesethmoid wide, separating completely the premaxillary ( $v s$. short projection, not separating completely the premaxillary). It may be further separated from $P$. heterostomus by presence of 36-43 perforated scales on the lateral line (vs. 45-56 perforated scales).

Description. Morphometric data presented in Table 1. Body moderately compressed and deep, less so in individuals of less than $150 \mathrm{~mm}$ SL, greatest body depth within region delimited anteriorly by vertical through insertion of pelvic fin and posteriorly by vertical through origin of dorsal fin. Average body depth variable among population samples, but with broad overlap in ranges among examined samples. Dorsal profile of head distinctly convex from margin of upper lip to 

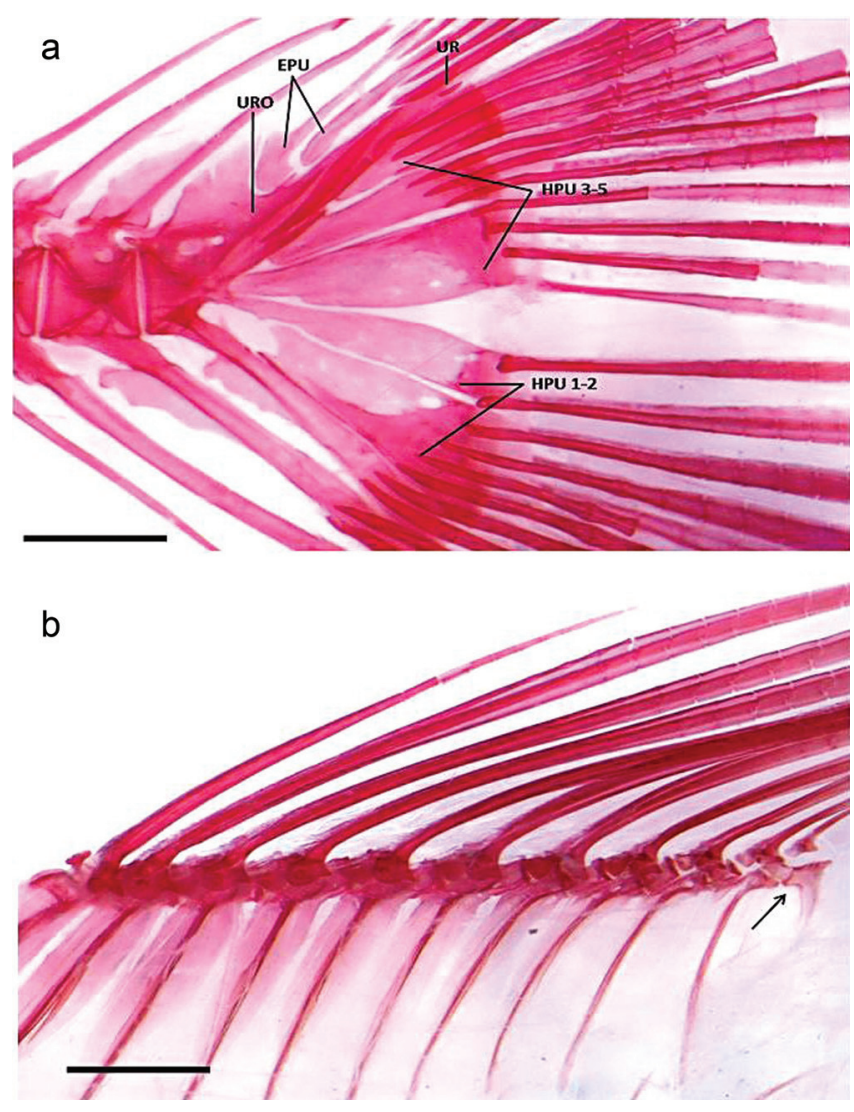

Fig. 8. Caudal skeleton, lateral view (a) and dorsal-fin pterygiophores and rays, lateral view (b) of Probolodus sazimai, MCP 13813, paratype, 43.5 mm SL. EPU: epurals, HPU 1-5: hypurals, UR: uroneurals, URO: urostyle. Scale bars $=1 \mathrm{~mm}$.

vertical through posterior nostril, straight to very slightly convex from latter point to tip of supraoccipital spine. Dorsal profile of body moderately convex from tip of supraoccipital spine to origin of dorsal fin, straight and posteroventrallyslanted along base of dorsal fin, straight to slightly convex from posterior terminus of base of dorsal fin to adipose fin, and slightly concave along caudal peduncle. Broad middorsal ridge present along predorsal region of body, with ridge less obvious anteriorly. Dorsal region of body between posterior terminus of dorsal fin and adipose fin transversely rounded overall, but slightly flattened middorsally in some individuals. Ventral profile of head slightly convex anteriorly from margin of lower lip approximately to vertical through anterior nares, then convex from that point to vertical through posterior margin of eye. Ventral profile of body convex to insertion of pelvic fin, nearly straight but slightly posteroventrally-aligned from that point to origin of anal fin, straight to slightly convex and posterodorsally-slanted along base of anal fin, and slightly concave along caudal peduncle. Prepelvic region of body somewhat flattened transverselly.

Head obtusely rounded anteriorly in lateral profile. Mouth terminal. Upper jaw with maxilla distinctly posteroventrallyangled relative to ventral margin of premaxilla and extending ventral of orbit to point somewhat short of, or reaching, vertical through anterior margin of pupil. Nares of each side of head very close together; anterior opening circular, posterior crescent-shaped with distinct flap between nares. Eye relatively large and lacking distinct adipose eyelid. Median fronto-parietal fontanel extending from mesethmoid to supraoccipital spine. Width of fontanel approximately onefifth distance across bony interorbit. Infraorbital series complete with third infraorbital by far largest. All infraorbitals carrying laterosensory canal segments proximate to margin of orbital rim. Supraorbital absent. Branchiostegal rays four. Gill-rakers long and setiform; $10-12+1+7-8$ rakers present on first gill-arch.

Teeth on premaxillary, maxillary, and dentary in one row. Premaxilla with three (9) or four (2) teeth [three] somewhat directed outward; each tooth with three points in angles of a nearly isosceles triangle; middle point, which is also the anterior one, much larger. Maxilla with three to six (commonly four) teeth [four] with two cusps of similar size, first two or three directed outward. Dentary, mostly, with six large teeth, first three directed outward, fourth, fifth, sometimes the sixty tricuspidate, and one or more smaller ones following it, directed upward; larger teeth of the lower jaw heavy, conical, with a minute cusp on each side; in overall, dentary has five to six (commonly five) tricuspidate teeth [five].

Scales cycloid, relatively large, and firmly implanted. Lateral line decurved anteriorly approximately to vertical through origin of dorsal fin, then slightly posterodorsallyangled to caudal peduncle, and then running horizontally to terminus of scale series. Lateral line completely pored from supracleithrum to base of caudal fin and followed posteriorly by assified tubular extension running along lateral margin of membrane joining middle rays of caudal fin. Lateral-line scales 36 (2), 38 (2), 39 (1), 40 (3), or 43 (2) [42]; scales in transverse series from origin of dorsal fin to lateral line 7 (10) or 8 (1) [7]; scales in transverse series from insertion of pelvic fin to lateral line 6 (11) [6]; scales in transverse series from origin of anal fin to lateral line 6 (1) or 7 (10) [7]; scales along middorsal line between tip of supraoccipital process and origin of dorsal fin 12 (9) or 13 (2) [12]; scales along middorsal line between posterior termination of base of dorsal fin and adipose fin 12 (11) [12]; horizontal scale rows around caudal peduncle 14 (6), 15 (1), or 16 (2) [16]. Vertebrae $33(\mathrm{n}=4), 34(\mathrm{n}=4), 35(\mathrm{n}=$ 2), or $36(n=1)$ [34].

Dorsal-fin rays ii,9 (11) [ii,9]. Anal-fin rays iv (7) or v (4), 22 (1), 23 (2), 24 (4), 25 (1), 26 (2), or 27 (1) [v,25]. Pectoral-fin rays i,10,i (4), i,11 (1), i,11,i (5), or i,12 (1) [i,10,i]. Pelvic-fin rays i,6 (2), i,6,i (1), or i,7 (7) [i,6,i]. Principal caudal-fin rays i,17,i (11) [i,17,i].

Dorsal-fin margin distally rounded to slightly truncate; first unbranched ray approximately $40-50 \%$ length of second unbranched ray. Dorsal-fin origin situated along vertical located approximately at middle of SL. Origin of adipose fin located slightly anterior of vertical through posterior terminus of base of anal fin. Profile of adpressed pectoral fin distinctly acute. Tip of pectoral fin extending approximately to vertical 
through insertion of pelvic fin. Profile of expanded pelvic fin pointed, with first branched ray either longest in fin or subequal to unbranched ray. Insertion of pelvic fin located distinctly anterior to vertical through origin of dorsal fin. Tip of adpressed pelvic fin extending approximately to vertical through insertion of anal fin. Some larger, apparently male, specimens with posteriorly-directed hooks along posterior margins of second through seventh pelvic-fin rays; hooks rarely also present on first ray. Hooks limited to posterior branch of hook-bearing rays. Each hook-bearing segment typically with one hook, although two hooks occasionally present on some segments. Distal margin of anal fin slightly concave in which fourth or fifth unbranched and first and second branched rays longest and subequal or first through third branched rays longest with subsequent branched rays gradually decreasing in length. Some larger, apparently male, individuals with hooks present on various rays gradually of anal fin. Hooks most often arise along posterior margin of posterior branch of second through seventh branched rays. Hooks extending onto unbranched segments of some rays. Caudal fin forked, with distal margins of lobes obtusely pointed.

Color in alcohol. Overall ground color of body in specimens fixed in formalin yellowish brown. Guanine remaining on lateral and ventral portions of head and on ventral and, to a variable degree, lateral surfaces of body. Snout and dorsal portion of head relatively dark. Middorsal and immediately adjoining portions of body relatively dark. Distinct, wedge-shaped, ventrally-attenuated humeral blotch with irregular margins

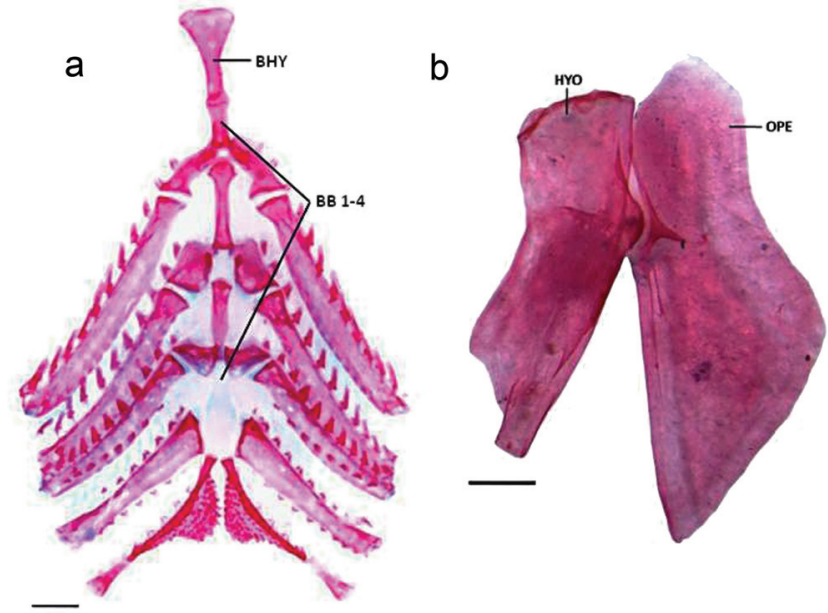

Fig. 9. Branchial skeleton, dorsal view (a) and posterior region of suspensorium (b) of Probolodus sazimai, MCP 13813, paratype, $43.5 \mathrm{~mm}$ SL. BHY: basihyal, BB 1-4: first to fourth basibranchials, HYO: hyomandibula, OPE: opercle. Scale bars $=1 \mathrm{~mm}$.

extending from approximately five scales dorsal of lateral line to about two scales ventral of lateral line. Pigmentation of humeral blotch typically most intense in region dorsal of lateral line, with pigmentation of remaining ventral portion of blotch variably lighter, but still quite obvious. Dark midlateral pigmentation more conspicuous on portion of body beginning at vertical through anterior portion of dorsal fin, with stripe widening posteriorly on caudal peduncle into distinct,

Table 1. Morphometrics of Probolodus heterostomus, P.oyakawai, and P. sazimai. Standard length is expressed in millimeters; measurements 1-16 as percentages of standard length; 17-22 as percentages of head length.

\begin{tabular}{|c|c|c|c|c|c|c|c|c|c|}
\hline & \multicolumn{3}{|c|}{ P. heterostomus $(\mathrm{n}=160)$} & \multicolumn{3}{|c|}{ P. oyakawai $(\mathrm{n}=38)$} & \multicolumn{3}{|c|}{ P. sazimai $(\mathrm{n}=12)$} \\
\hline & Holotype & Range & Mean & Holotype & Range & Mean & Holotype & Range & Mean \\
\hline Standard length & 49.0 & $16.3-100.8$ & 52.9 & 40.6 & 21.4-64.3 & 39.6 & 56.7 & $36.7-56.7$ & 46.8 \\
\hline \multicolumn{10}{|c|}{ Percents of standard length } \\
\hline Greatest body depth & 37.2 & $31.8-46.0$ & 38.5 & 34.4 & $33.2-45.6$ & 37.7 & 39.9 & 34.1-41.7 & 38.8 \\
\hline Snout to dorsal-fin origin & 51.3 & 49.3-58.6 & 53.3 & 52.7 & $50.5-55.6$ & 53.6 & 54.1 & 50.3-58.1 & 53.9 \\
\hline Snout to pectoral-fin origin & 26.8 & 23.3-32.9 & 28.3 & 26.1 & $25.5-32.4$ & 28.7 & 27.2 & $26.8-32.2$ & 29.1 \\
\hline Length of base of dorsal fin & 12.1 & $11.3-16.4$ & 14.3 & 12.3 & $12.3-16.3$ & 14.1 & 13.8 & $11.3-16.1$ & 14.3 \\
\hline $\begin{array}{l}\text { Posterior terminus of base of dorsal fin to } \\
\text { adipose fin }\end{array}$ & 25.1 & 21.5-31.9 & 27.7 & 26.3 & 23.7-29.7 & 26.7 & 27.2 & $25.2-29.3$ & 26.7 \\
\hline $\begin{array}{l}\text { Posterior terminus of dorsal fin to caudal-fin } \\
\text { base }\end{array}$ & 39.2 & $36.2-44.2$ & 40.6 & 38.6 & 36.6-46.1 & 40.2 & 41.1 & $32.8-42.6$ & 39.7 \\
\hline Snout to insertion of pelvic fin & 47.0 & 43.4-53.5 & 47.8 & 45.3 & $42.5-49.8$ & 47.2 & 47.6 & $47.6-52.3$ & 49.3 \\
\hline Snout to anus & 59.0 & $45.9-64.0$ & 58.7 & 54.4 & $52.3-66.0$ & 57.2 & 63.5 & $55.0-64.7$ & 60.4 \\
\hline Snout to origin of anal fin & 64.4 & 59.6-73.2 & 65.2 & 61.3 & $61.2-72.4$ & 64.8 & 69.3 & $63.8-70.1$ & 66.4 \\
\hline Length of base of anal fin & 33.3 & 29.3-38.7 & 34.1 & 30.3 & 29.7-37.7 & 33.4 & 32.5 & 26.6-34.6 & 32.6 \\
\hline Length of caudal peduncle & 12.1 & 09.4-14.8 & 11.0 & 10.3 & 08.4-13.8 & 11.2 & 11.9 & 10.1-13.3 & 11.4 \\
\hline Length of longest dorsal-fin ray & 28.4 & $25.8-34.7$ & 30.5 & 29.3 & 29.3-34.6 & 31.4 & 28.4 & $22.2-34.6$ & 29.9 \\
\hline Length of longest anal-fin ray & 16.7 & $16.4-25.8$ & 20.7 & 22.1 & $18.6-25.8$ & 22.4 & 20.3 & $19.1-22.5$ & 20.8 \\
\hline Length of longest pectoral-fin ray & 20.3 & $17.7-28.3$ & 21.3 & 17.2 & $17.2-25.4$ & 21.3 & 20.9 & $19.6-23.3$ & 22.2 \\
\hline Length of longest pelvic-fin ray & 15.1 & $14.6-19.8$ & 17.3 & 17.4 & $14.8-20.9$ & 17.1 & 16.6 & $16.6-20.4$ & 18.6 \\
\hline Least depth of caudal peduncle & 11.2 & $09.0-13.4$ & 11.6 & 10.3 & $09.3-13.2$ & 11.2 & 12.6 & 11.4-12.7 & 12.0 \\
\hline Head length & 25.8 & 24.1-30.2 & 27.6 & 27.0 & $26.5-30.5$ & 28.1 & 25.8 & 25.4-31.7 & 27.4 \\
\hline \multicolumn{10}{|c|}{ Percents of head length } \\
\hline Head height & 89.1 & 72.3-98.6 & 85.4 & 81.0 & 74.3-92.5 & 84.1 & 90.4 & 85.5-92.2 & 89.2 \\
\hline Snout length & 27.0 & $26.0-29.3$ & 27.4 & 28.2 & 26.1-28.9 & 27.3 & 26.7 & 26.6-28.7 & 27.6 \\
\hline Orbital diameter & 37.4 & $26.6-46.8$ & 38.5 & 38.1 & $32.9-45.3$ & 38.3 & 37.0 & $35.7-42.4$ & 38.9 \\
\hline Postorbital head length & 45.0 & 33.7-52.6 & 42.9 & 40.9 & $36.0-47.6$ & 42.3 & 45.2 & 39.4-50.4 & 44.6 \\
\hline Interorbital width & 33.8 & 27.7-38.9 & 33.6 & 30.9 & 27.4-41.1 & 32.8 & 36.3 & 25.2-37.2 & 33.8 \\
\hline
\end{tabular}


horizontally-elongate, ovoid blotch. Pigmentation of blotch more intense than that of remainder of stripe. Chromatophores of dorsal portion are concentrated at the base and middle region of the scales, its margins being free of chromatophores. Region below the lateral line decreases the concentration of chromatophores, and, between the anal fin and caudal peduncle, sparse chromatophores are present in greater proportion.

Dorsal, anal, and caudal fins with interradial membranes covered by small dark chromatophores, with chromatophores often more concentrated proximate to margins of fin rays. Dark pigmentation on caudal fin more intense along middle fin-rays in most specimens and forming stripe variably continuous anteriorly with midlateral dark blotch on caudal peduncle. Anal fin with unbranched rays and all branched rays pigmented. Distal half of remainder of fin with dark chromatophores in all individuals, with fields of chromatophores extending nearly to base of fin membranes. Adipose fin lightly colored overall, but often freckled with small dark spots. Pectoral and pelvic fins with small, dark spots located both along fin-ray margins.

Distribution. Probolodus sazimai is known to occur in the rios Itapemirim and Doce basins (Espírito Santo and Minas Gerais states, respectively), southeastern Brazil. (Fig. 2).

Ecological notes. Ctenoid and cycloid fish scales were observed in the stomach contents and between gill rakers of one specimen (MCP 13813, 1, 43.5 mm SL). No other items could be identified, possibly due to their advanced state of decomposition. Leaf fragments, insects and scales were observed in the oral cavity of three specimens preserved in alcohol (LBP 3433, 1, 45.1 mm SL; MCP 13813, 2, 36.8-54.4 $\mathrm{mm}$ SL).

Etymology. The species name, sazimai, is in honor of Ivan Sazima from Museu de Zoologia of UNICAMP (ZUEC-PIS), in appreciation of his contributions to our knowledge of the Neotropical lepidophagous caraciforms.

\section{Notes on phylogenetics relationships and biogeography of Probolodus}

The monophyly of Probolodus is supported by five exclusive characteristics, and three non-exclusive characteristics. Of all the characteristics shared among species of the genus, there are at least two exclusive characteristics, such as the presence on premaxillary and dentary of tricuspid teeth, with median cusp greatly developed and pointed outward, most probably related to the lepidophagous habit these species (Fig. $1 \mathrm{a}-\mathrm{c}$ ).

The genera of Neotropical characiforms Bryconexodon, Catoprion, Exodon, Roeboexodon, Roeboides, and Serrabrycon also exhibit specialized dentitions favoring the lepidophagous habit, such as pointed by Sazima (1977), Sazima \& Uieda (1980), Sazima \& Machado (1982) and Sazima (1983). However, specialized teeth directed out of the mouth is a diagnostic characteristic which allows easy recognition of lepidophagous taxa, although, the shape, number and the differential arrangement these conical and mammiliform, or cuspidate teeth on premaxillary, maxillary and dentary in these species are fundamental for understanding of evolution this character in independent lineages of Neotropical lepidophagous characiforms, as demonstrated by some authors (e.g., Roberts, 1970; Géry, 1980; Sazima, 1983; Vari, 1986; Lucena, 1998; Mirande, 2010; Mattox \& Toledo-Piza, 2012). Thus, the specialized dentition of Probolodus, as well as the predatory behavior of plucking and eating scales could have evolved independently in Bryconexodon, Exodon, and Roeboexodon. Among the shared characteristics that support evolutionary relationships among these three taxa, we highlight some related to the structure and arrangement of teeth, mainly: the teeth of these characids are stout with hypertrophied bases, conical, and especially in the dentary, the larger teeth have compressed and cuspidate crowns, being unicupidate or bicuspidate and directed upwards; larger cuspidate teeth arranged with conical smaller teeth, and are recurved posteriorly relative to the body; in the premaxillary there is a outward mammiliform tooth developed and directed forward.

Probolodus has been treated as a monophyletic group of lepidophagous characids evolutionarily related to the Tetragonopterinae (sensu Roberts, 1970; sensu Géry, 1977; 1980; and sensu Mirande, 2010). Thus, the hypothesis of Sazima (1977), considers the similarity of Probolodus with the Tetragonopterinae (sensu Géry, 1977) a form of aggressive mimicry, (i.e., similarity due to mimicry and not to phylogenetic proximity), whereas the Tetragonopterinae (sensu Géry, 1977), Astyanax fasciatus and coastal sympatric species of the genus Deuterodon are probably the usual prey of the species of Probolodus.

The species of the genus Probolodus are distributed throughout the coastals drainages of eastern Brazil (from Espírito Santo to São Paulo states) which according to Ribeiro (2006) corresponds to an area of great biogeographical significance due to high degree of endemism in its fish fauna (Fig. 2). Meanwhile, the eastern coastal systems have already been considered as areas of endemism by various authors (e.g., Eigenmann, 1909; Géry, 1969; Vari, 1988; Weitzman et al., 1988; Menezes, 1996) and recognition of these areas in the coastal drainages of South and Southeast of Brazil is similar or quite congruent with the distribution of the genus Deuterodon by Lucena \& Lucena (1992; 2002) and Pereira (2010), Mimagoniates by Menezes \& Weitzman (1990), Spintherobolus by Weitzman \& Malabarba (1999), Hemipsilichthys by Pereira \& Reis (2002), Hollandichthys by Bertaco (2003), Phalloptychus by Lucinda (2005), Phalloceros by Lucinda (2008).

However, the coastal streams have been historically connected with the adjacent upland crystalline shield. Thus, geological events were responsible to the capture of adjacent upland high areas, and consequently the capture of upland streams, such as the formation of the upper rio Paraíba do Sul 
by capturing streams of the rio Tietê ( $c f .$, Ab'Saber, 1957; Menezes, 1972; Weitzman et al., 1988; Langeani, 1989; Bizerril, 1994; M. Malabarba, 1998; Weitzman \& Malabarba, 1999; Bizerril \& Lima, 2000; Oliveira \& Britski, 2000; Quevedo \& Reis, 2002; Oyakawa et al., 2005; Ribeiro et al., 2006; Lucinda, 2008). Therefore, possible effects of tectonics, changing the topography of the terrain and, thus, influencing the capture of coastal streams, especially in the southeastern (Ab'Saber, 2003; Cobbold et al., 2001; Ribeiro, 2006) and fluctuations in sea level in the Pleistocene, allowing the union of several rivers and coastal streams, favoring the isolation of populations and speciation events (Weitzman et al., 1988; Weitzman \& Malabarba, 1999; Ribeiro, 2006), are, probably, related to the divergence of the species of Probolodus.

Comparative material examined. Aphyocharax pusillus, LIRP 4559, 2, 39.6-45.4 mm SL; Astyanax fasciatus, LIRP 132, 3, 71.975.4 mm SL; Brycon pesu, LIRP 5962, 2, 73.3-82.9 mm SL; Bryconexodon juruenae, LIRP 7139, 2, 89.8-98.8 mm SL; Bryconops alburnoides, LIRP 5116, 2, 94.0-110.7 mm SL; Cheirodon galusdae, LIRP 5958, 3, 38.7-45.0 mm SL; Deuterodon iguape, LIRP 1059, 2, 83.2-86.5 mm SL; Exodon paradoxus, LIRP 5933, 2, 59.6-62.8 mm SL; Gymnocorymbus thayeri, MZUSP 17468, 2, 44.8-46.6 mm SL; Hemigrammus unilineatus, MZUSP 30322, 2, 30.1-33.2 mm SL; Hollandichthys multifasciatus, LIRP 5744, 2, 70.6-86.5 mm SL; Hyphessobrycon eques, LIRP 1835, 2, 29.6-30.9 mm SL; Jupiaba anteroides, MZUSP 17929, 3, 63.6-74.4 mm SL; Moenkhausia xinguensis, MZUSP 91690, 2, 59.8-64.6 mm SL; Oligosarcus pintoi, LIRP 300, 2, 75.2-82.06 mm SL; Poptella paraguayensis, LIRP 5940, 2, 35.2-39.8 mm SL; Roeboexodon guyanensis, MZUSP 91949, 2, 83.4-83.8 mm SL; Tetragonopterus argenteus, LIRP 5941, 2, 49.7-56.1 mm SL.

\section{Identification key of Probolodus}

1. Perforated scales on the lateral line $45-56$ (48 most frequent); $18-21$ scale series around the caudal peduncle (18 most frequent); 34-35 totals vertebrae (35 most frequent) $P$. heterostomus

(Figs. 2, 3) (rio Paraíba do Sul basin)

1'. Perforated scales on the lateral line 36-43; 14-16 scale series around the caudal peduncle (14 most frequent); 33-36 totals vertebrae (33 and 34 are most frequent) ....

2. Seven or eight transverse series of scales from insertion of pelvic fin to lateral line (seven most frequent, eight infrequent); 13-16 scales along middorsal line between posterior terminus of base of dorsal fin and adipose fin (15 most frequent) P. oyakawai

(Figs. 2, 5) (rio Ribeira de Iguape basin)

2'.Six transverse series of scales from insertion of pelvic fin to lateral line; 12 scales along middorsal line between posterior terminus of base of dorsal fin and adipose fin P. sazimai

(Figs. 2, 7) (tributaries of the rio Itapemirim and drainages of the rio Doce basin)

\section{Acknowledgments}

This paper represents the major part of the Master Dissertation of O. Santos at Universidade de São Paulo (Faculdade de Filosofia, Ciências e Letras de Ribeirão Preto, Dept. Biologia, PPG Biologia Comparada), completed under the supervision of R. M. C. Castro and supported by a scholarship from the Coordenação de Pessoal de Nível Superior (CAPES). F. A. Bockmann (Faculdade de Filosofia, Ciências e Letras de Ribeirão Preto, Universidade de São Paulo) and O. T. Oyakawa (MZUSP), members of the dissertation committee of O. Santos, provided valuable suggestions on an earlier version of this work. For critical review of the manuscript we thank two anonymous reviewers. We are very grateful to the following individuals and institutions for the loan of specimens and other information relevant to this work: P. W. Willink and M. A. Rogers (FMNH); C. de Oliveira (LBP); C. A. Lucena and Z. M. Lucena (MCP); P. A. Buckup (MNRJ); O. T. Oyakawa and J. L. de Figueiredo (MZUSP); R. P. Vari (USNM); and I. Sazima (ZUEC-PIS). We are very grateful to P. W. Willink by the sending of photographs of type-material, and by the carrying out the measurements and counts of the holotype of $P$. heterostomus. A. C. Aquino cleared and stained several specimens used in this work and helped in using the photographic equipment. V. Slobodian helped to use the X-ray equipment. M. Pastana and T. Pereira helped in editing the figures. This paper is part of the FAPESP Thematic Project "Phylogenetic relationships in the Characidae (Ostariophysi: Characiformes)" (Grant 04/ 09219-6). Research funding for this study came also from the Conselho Nacional de Desenvolvimento Científico e Tecnológico (CNPq: 307554/2010-4 to R. M. C. Castro and CNPq: 141525/2012-6 to O. Santos - doctorate scholarship).

\section{Literature Cited}

Ab’Saber, N. A. 1957. O problema das conexões antigas e da separação da drenagem do Paraíba e Tietê. Boletim Paulista de Geografia, 26: 38-49.

Ab’Saber, N. A. 2003. Megamorfologia do território brasileiro. Pp. 71-106. In: Cunha, S. B. \& A. J. T. Guerra (Eds.). Bertand Brasil, $3^{\mathrm{a}}$ ed., Rio de Janeiro.

Azevedo, M. 2010. Reproductive characteristics of characid fish species (Teleostei, Characiformes) and their relationship with body size and phylogeny. Iheringia, Série Zoologia. Porto Alegre, 100: 469-482.

Bertaco, V. A. 2003. Taxonomia e filogenia do gênero Hollandichthys Eigenmann, 1909 (Teleostei: Characidae) do Sul e Sudeste do Brasil. Unpublished MS.c Dissertation, Pontifícia Universidade Católica do Rio Grande do Sul, Porto Alegre, 152p.

Bizerril, C. R. S. F. 1994. Análise taxonômica e biogeográfica da ictiofauna de água doce do leste brasileiro. Acta Biological Leopoldensia, 16: 51-80.

Bizerril, C. R. S. F. 1999. A ictiofauna da bacia do rio Paraíba do Sul. Biodiversidade e padrões biogeográficos. Brazilian Archives of Biology and Technology, 42: 233-250. 
Bizerril, C. R. S. F. \& N. R. M. Lima. 2000. Levantamento da ictiofauna da bacia do rio Ribeira de Iguape, Brasil. Acta Biological Leopoldensia, 22: 103-110.

Buckup, P. A., N. A. Menezes \& M. S. Ghazzi (Eds.). 2007. Catálogo das espécies de peixes de água doce do Brasil. Séries livro 23, Museu Nacional, Rio de Janeiro.

Cobbold, P. R., K. E. Meisling \& V. S. Mount. 2001. Reactivation of an obliquely rifted margin, Campos and Santos basins, Southeastern, Brazil. American Association of Petroleum Geologists Bulletin, 85: 1925-1944.

Eigenmann, C. H. 1909. The fresh-water fishes of Patagonia and an examination of the Archiplata-Archhelenis theory. Pp: 225-274. In: Reports of the Princeton University Expeditions to Patagonia 1896-1899. Princeton University \& Stuttgart, Part 3.

Eigenmann, C. H. 1911. New Characins in the collection of the Carnegie Museum. Annals Carnegie Museum, 8: 164-181.

Eigenmann, C. H. 1915. The Cheirodontinae, a subfamily of minute characid fishes of South America. Memoirs of the Carnegie Museum, 7: 1-99.

Fink, W. L. \& S. H. Weitzman. 1974. The so-called cheirodontin fishes of Central America with descriptions of two new species (Pisces, Characidae). Smithsonian Contributions to Zoology, 172: 1-46.

Géry, J. 1969. The fresh-water fishes of South America. Pp: 828848. In: Fitkau, E. J., H. Illies, H. Klinge, G. H. Schwabe, H. Sioli (Eds.). Biogeography and Ecology in South America. Dr. W. Junk N. V. Publishers, The Hague.

Géry, J. 1977. Characoids of the World. Neptune city. T. F. H. Publications, Inc.

Géry, J. 1980. Un nouveau poisson characoide occupant la niche des mangeurs d'écailles dans le haut rio Tapajoz, Brésil: Bryconexodon juruenae n.g.sp. Revue Française d'Aquariologie, 7: 1-8.

Ibarra, M. \& D. J. Stewart. 1987. Catalogue of Type Specimens of Recent fishes in Field Museum of Natural History. Fieldiana Zoology, 35.

Janovetz, J. 2005. Functional morphology of feeding in the scaleeating specialist Catoprion mento. The Journal of Experimental Biology, 208: 4757-4768.

Jégu, M., G. M. dos Santos \& E. Ferreira. 1991. Une nouvelle espèce de Bryconexodon (Pisces, Characidae) décrite du bassin du Trombetas (Para, Brésil). Journal of Natural History, 25: 773-782.

Jordan, D. S. 1920. The genera of fishes. Part IV. From 1881 to 1920, thirty-nine years, with the accepted type of each. A contribution to the stability of scientific nomenclature. Leland Stanford Junior University Publications, University Series, 43: 411-576.

Langeani, F. 1989. Ictiofauna do Alto Curso do rio Tietê (SP): Taxonomia. Unpublished MS.c. Dissertation, Universidade de São Paulo, São Paulo, 231p.

Lima, F. C. T., L. R. Malabarba, P. A. Buckup, J. F. Pezzi da Silva, R. P. Vari, A. Harold, R. Benine, O. T. Oyakawa, C. S. Pavanelli, N. A. Menezes, C. A. S. Lucena, M. C. S. L. Malabarba, Z. M. S. Lucena, R. E. Reis, F. Langeani, L. Casatti, V. A. Bertaco, C. Moreira \& P. H. F. Lucinda. 2003. Genera incertae sedis in Characidae. Pp. 106-169. In: Reis, R. E., S. O. Kullander \& C. J. Ferraris (Eds.). Check List of the Freshwater Fishes of South and Central America. Porto Alegre, Edipucrs.

Lucena, C. A. S. 1998. Relações filogenéticas e definição do gênero Roeboides Günther (Ostariophysi; Characiformes; Characidae). Comunicações do Museu de Ciências e Tecnologia da PUCRS, Série Zoologia, 11: 19-59.
Lucena, C. A. S. \& Z. M. S. Lucena. 2002. Redefinição do gênero Deuterodon Eigenmann (Ostariophysi: Characiformes: Characidae). Comunicações do Museu de Ciências e Tecnologia da PUCRS, Série Zoologia, 15: 113-135.

Lucena, Z. M. S. \& C. A. S. Lucena. 1992. Revisão das espécies do gênero Deuterodon Eigenmann, 1907 dos sistemas costeiros do sul do Brasil, com a descrição de quatro espécies novas (Ostariophysi: Characiformes: Characidae). Comunicações do Museu de Ciências e Tecnologia da PUCRS, Série Zoologia, 5: 123-168.

Lucinda, P. H. F. 2005. Systematics and biogeography of the genus Phalloptychus Eigenmann, 1907 (Cyprinodontiformes: Poeciliidae: Poeciliinae). Neotropical Ichthyology, 3: 373-382.

Lucinda, P. H. F. 2008. Systematics and biogeography of the genus Phalloceros Eigenmann, 1907 (Cyprinodontiformes: Poeciliidae: Poeciliinae), with the description of twenty-one new species. Neotropical Ichthyology, 6: 113-158.

Malabarba, L. R. 1998. Monophyly of the Cheirodontinae, Characters and Major Clades (Ostariophysi: Characidae). Pp. 193-234. In: Malabarba, L. R., R. E. Reis, R. P. Vari, Z. M. S. Lucena \& C. A. S. Lucena (Eds.). Phylogeny and classification of Neotropical fishes. Porto Alegre, Edipucrs, 603p.

Malabarba, M. C. S. L. 1998. Phylogeny of fossil Characiformes and paleobiogeography of Tremembé formation, São Paulo, Brazil. Pp. 69-84. In: Malabarba, L. R., R. E. Reis, R. P. Vari, Z. M. S. Lucena \& C. A. S. Lucena (Eds.). Phylogeny and classification of Neotropical fishes. Porto Alegre, Edipucrs.

Mattox, G. M. T. \& M. Toledo-Piza. 2012. Phylogenetic study of the Characinae (Teleostei: Characiformes: Characidae). Zoological Journal of the Linnean Society, 165: 809-915.

Menezes, N. A. 1972. Distribuição e origem da fauna de peixes de água doce das grandes bacias fluviais do Brasil. Pp. 79-108. In: Comissão Internacional da bacia Paraná/Uruguai. Poluição e Piscicultura, Faculdade e Saúde Pública da USP e Instituto de Pesca, São Paulo.

Menezes, N. A. 1996. Methods for assessing freshwater fish diversity. Pp: 289-295. In: Bicudo, C. E. M. \& N. A. Menezes (Eds.). Biodiversity in Brazil: a first approach. São Paulo: CNPq.

Menezes, N. A., O. T. Oyakama, R. M. C. Castro, S. H. Weitzman, F. C. T. Lima \& M. J. Weitzman. 2007. Peixes de água doce da Mata Atlântica: lista preliminar das espécies e comentários sobre conservação de peixes de água doce neotropicais. São Paulo: Museu de Zoologia - Universidade de São Paulo.

Menezes, N. A. \& S. H. Weitzman. 1990. Two new species of Mimagoniates (Teleostei: Characidae: Glandulocaudinae), their phylogeny, and biogeography and a key to the glandulocaudin fishes of Brazil and Paraguay. Proceedings of the Biological Society of Washington, 103: 380-426.

Mirande, J. M. 2007. Filogenia de Characidae (Teleostei, Characiformes) y optimización autopesada. VII Reunión Argentina de Cladística y Biogeografia: Darwiniana, 45: 19-23.

Mirande, J. M. 2009. Weighted parsimony phylogeny of the family Characidae (Teleostei: Characiformes). Cladistics, 25: 1-40.

Mirande, J. M. 2010. Phylogeny of the family Characidae (Teleostei: Characiformes): from characters to taxonomy. Neotropical Ichthyology, 8: 385-568.

Mirande, J. M., G. Aguilera \& M. M. Azpelicueta. 2011. A threatened new species of Oligosarcus and its phylogenetics relationships, with comments on Astyanacinus (Teleostei: Characidae). Zootaxa, 2994: 1-20.

Myers, G. S. 1942. Studies on South American fresh-water fishes. I. Stanford Ichthyological Bulletin, 2: 89-114. 
Nelson, J. S. 2006. Fishes of the World. John Wiley \& Sons, New York.

Oliveira, C., G. S. Avelino, K. T. Abe, T. C. Mariguela, R. C. Benine, G. Ortí, R. P. Vari \& R. M. C. Castro. 2011. Phylogenetic relationships within the speciose family Characidae (Teleostei: Ostariophysi: Characiformes) based on multilocus analysis and extensive ingrooup sampling. BMC Evolutionary Biology, 11: 275.

Oliveira, J. C. \& H. A. Britski. 2000. Redescrição de Taunaya bifasciata (Eigenmann \& Norris, 1900) comb. nova, um bagre enigmático do Estado de São Paulo (Siluriformes, Pimelodidae, Heptapterinae). Papéis Avulsos de Zoologia, São Paulo, 41: 119-133.

Oyakawa, O. T., A. Akama, K. C. Mautari \& J. C. Nolasco. 2006. Peixes de Riachos da Mata Atlântica nas Unidades de Conservação do Vale do Rio Ribeira de Iguape no Estado de São Paulo. Editora Neotrópica, São Paulo.

Oyakawa, O. T., A. Akama, A. M. Zanata. 2005. Review of the genus Hypostomus Lacépède, 1803 from Ribeira do Iguape basin, with descriptions of a new species (Pisces, Siluriformes, Loricariidae). Zootaxa, 921: 1-27.

Pearson, N. E. 1937. The fishes of the Beni-Mamoré and Paraguay basins, and a discussion of the origin of the Paraguayan fauna. Proccedings of the California Academy of Sciences, 23: 99-114.

Pereira, E. H. L. \& R. E. Reis. 2002. Revision of loricariid genera Hemipsilichthys and Isbrueckerichthys (Teleostei: Siluriformes), with descriptions of five new species of Hemipsilichthys. Ichthyological Exploration of Freshwaters, 13: 271-276.

Pereira, T. N. A. 2010. Filogenia das espécies de Deuterodon Eigenmann, 1907 (Characiformes: Characidae), um gênero de lambaris da Mata Atlântica. Unpublished MS.c.Dissertation. Instituto de Biociências, Universidade Estadual Paulista "Júlio de Mesquita Filho", Botucatu, 265p.

Pinto, B. C. T., M. G. Peixoto \& F. G. Araújo. 2006. Effects of the proximity from an industrial plant on fish assemblages in the rio Paraíba do Sul, southeastern Brazil. Neotropical Ichthyology, 4: 269-278.

Quevedo, R. \& R. E. Reis. 2002. Pogonopoma obscurum: a new species of loricariid catfish (Siluriformes: Loricariidae) from southern Brazil, with comments on the genus Pogonopoma. Copeia, 2002: 402-410.

Reis, R. E. 2003. Subfamily Tetragonopterinae. Pp. 212. In: Reis, R. E., S. O. Kullander \& C. J. Ferraris (Eds.). Check List of the Freshwater Fishes of South and Central America. Porto Alegre, Edipucrs.

Reis, R. E., S. O. Kullander \& C. J. Ferraris (Eds.). 2003. Check List of the Freshwater Fishes of South and Central America. Porto Alegre, Edipucrs.

Ribeiro, A. C. 2006. Tectonic history and the biogeography of the freshwater fishes from the coastal drainages of eastern Brazil: an example of faunal evolution associated with a divergent continental margin. Neotropical Ichthiology, 4: 225-246.

Ribeiro, A. C., F. C. T. Lima, C. Riccomini \& N. A. Menezes. 2006. Fishes of the Atlantic rainforest of Boracéia: testimonies of the Quaternary fault reactivation within a Neoproterozoic tectonic province in Southeastern Brazil. Ichthyological Exploration of Freshwaters, 17: 157-164.

Roberts, T. R. 1970. Scale-eating American characoid fishes, with special reference to Probolodus heterostomus. Proceedings of the California Academy of Sciences, 20: 383-390.

Sazima, I. 1977. Possible case of aggressive mimicry in a neotropical scale-eating fish. Nature, 270: 510-512.
Sazima, I. 1983. Scale-eating in characoids and other fishes. Environmental Biology of Fishes, 9: 87-101.

Sazima, I. \& F. A. Machado. 1982. Habitats and behavior of Roeboides prognathus, a scale-eating fish (Osteichthyes: Characoidei). Boletim de Zoologia da Universidade de São Paulo, 7: 35-56.

Sazima, I. \& V. S. Uieda. 1980. Comportamento lepidofágico de Oligoplites saurus e registro de lepidofagia em $O$. palometa e $O$. saliens (Pisces, Carangidae). Revista Brasileira de Biologia, 40: 701-710.

Taylor, W. R. \& G. C. Van Dyke. 1985. Revised procedures for staining and clearing small fishes and other vertebrates for bone and cartilage study. Cybium, 9: 107-119.

Teixeira, T. P., B. C. T. Pinto, B. F. Terra, E. O. Estiliano, D. Gracia \& F. G. Araújo. 2005. Diversidade das assembléias de peixes nas quatro unidades geográficas do rio Paraíba do Sul. Iheringia Série Zoologia, Porto Alegre, 95: 347-357.

Vari, R. P. 1986. Serrabrycon magoi, a new genus and species of scale-eating characid (Pisces: Characiformes) from the upper Rio Negro. Proceedings of the Biological Society of Washington, 99: 328-334.

Vari, R. P. 1988. The Curimatidae, a lowland neotropical fish family (Pisces: Characiformes): distribution, endemism and phylogenetic biogeography. Pp: 343-377. In: Vanzolini, P. E. \& W. R. Heyer (Eds.). Proceedings of a Workshop on Neotropical Distribution Patterns. Academia Brasileira de Ciências, Rio de Janeiro.

Vari, R. P. \& R. M. C. Castro. 2007. New species of Astyanax (Ostariophysi: Characiformes: Characidae) from the Upper Rio Paraná System, Brazil. Copeia, 2007: 150-162.

Vari, R. P. \& A. S. Harold. 2001. Phylogenetic study of Neotropical of fish genera Creagrutus Günther and Piabina Reinhardt (Teleostei: Ostariophysi: Characiformes) with a revision of the cis-Andean species. Smithsonian Contributions to Zoology, 613: 1-239.

Weitzman, S. H. 1962. The osteology of Brycon meeki, a generalized characid fish, with an osteological definition of the family. Stanford Ichthyological Bulletin, 8: 3-77.

Weitzman, S. H. \& L. R. Malabarba. 1999. Systematics of Spintherobolus (Teleostei: Characidae: Cheirodontinae) from eastern Brazil. Ichthyological Exploration of Freshwaters, 10: $1-43$.

Weitzman, S. H., N. A. Menezes \& M. J. Weitzman. 1988. Phylogenetic biogeography of Glandulocaudini (Teleostei, Characiformes, Characidae) with comments on the distribution of other freshwater fishes in eastern and southeastern Brazil. Pp: 379-427. In: Vanzolini, P. E. \& W. R. Heyer (Eds.) Proceedings of a Workshop on Neotropical Distribution Patterns. Academia Brasileira de Ciências, Rio de Janeiro.

Zanata, A. M. \& A. Akama. 2004. Myxiops aphos, new characid genus and species (Characiformes: Characidae) from the rio Lençóis, Bahia, Brazil. Neotropical Ichthyology, 2: 45-54.

Submitted December 19, 2013 Accepted June 16, 2014 by Luiz R. Malabarba Published June 30, 2014 